\title{
Molecular evidence of a peripatric origin for two sympatric species of field crickets (Gryllus rubens and G. texensis) revealed from coalescent simulations and population genetic tests
}

\author{
DAVID A. GRAY,*HUATENG HUANG† and L. LACEY KNOWLES† \\ *Department of Biology, California State University, 18111 Nordhoff Street, Northridge, California 91330-8303, USA +Department of \\ Ecology and Evolutionary Biology, University of Michigan, Ann Arbor, Michigan 48109-1079, USA
}

\begin{abstract}
Species pairs that differ primarily in characters involved in mating interactions and are largely sympatric raise intriguing questions about the mode of speciation. When species divergence is relatively recent, the footprint of the demographic history during speciation might be preserved and used to reconstruct the biogeography of species divergence. In this study, patterns of genetic variation were examined throughout the geographical range of two cryptic sister taxa of field crickets, Gryllus texensis and G. rubens; mitochondrial cytochrome oxidase I (COI) was sequenced in 365 individuals sampled from 48 localities. Despite significant molecular divergence between the species, they were not reciprocally monophyletic. We devised several analyses to statistically explore what historical processes might have given rise to this genealogical structure. The analyses indicated that the biogeographical pattern of genetic variation does not support a model of recent gene flow between species. Instead, coalescent simulations suggested that the genealogical structure within $G$. texensis, namely a deep split between two geographically overlapping clades, reflects historical substructure within $G$. texensis. Additional tests that consider the concentration of $G$. rubens haplotypes in one of the two $G$. texensis genetic clusters suggest a model of speciation in which $G$. rubens was derived from one lineage of a geographically subdivided ancestor. These results indicate that, despite the contemporary sympatry of G. texensis and G. rubens, the data are indicative of an peripatric origin in which G. rubens was derived from one of the two historical partitions in the species currently recognized as G. texensis. This proposed model of species divergence suggests how the interplay of geography and selection may give rise to new species, although this requires testing with multilocus data. Specifically, the model highlights how that geographical partitioning of ancestral variation in the past may augment the selectively driven divergence of characters involved in the reproductive isolation of the species today.
\end{abstract}

Keywords: biogeography, Gryllus, speciation, statistical phylogeography

Received 14 March 2008; revision accepted 28 April 2008

\section{Introduction}

Research on species pairs with only slight morphological differences poses intriguing questions about the origin and maintenance of species distinctiveness. What are the reproductive isolating factors and what is the geographical

Correspondence: D. A. Gray, Fax: (818) 677-2034;

E-mail: dave.gray@csun.edu context under which those barriers evolved? Much of the focus on speciation in cryptic species has been on the former, with an emphasis on experiments that examine the consequences of differences in mating signals. For example, empirical work now complements theoretical models that rely upon strong assortative mating for species divergence in sympatry involving strong divergent sexual selection (e.g. Turner \& Burrows 1995; Payne \& Krakauer 1997; Higashi et al. 1999; Higgie et al. 2000; Takimoto et al. 2000) 


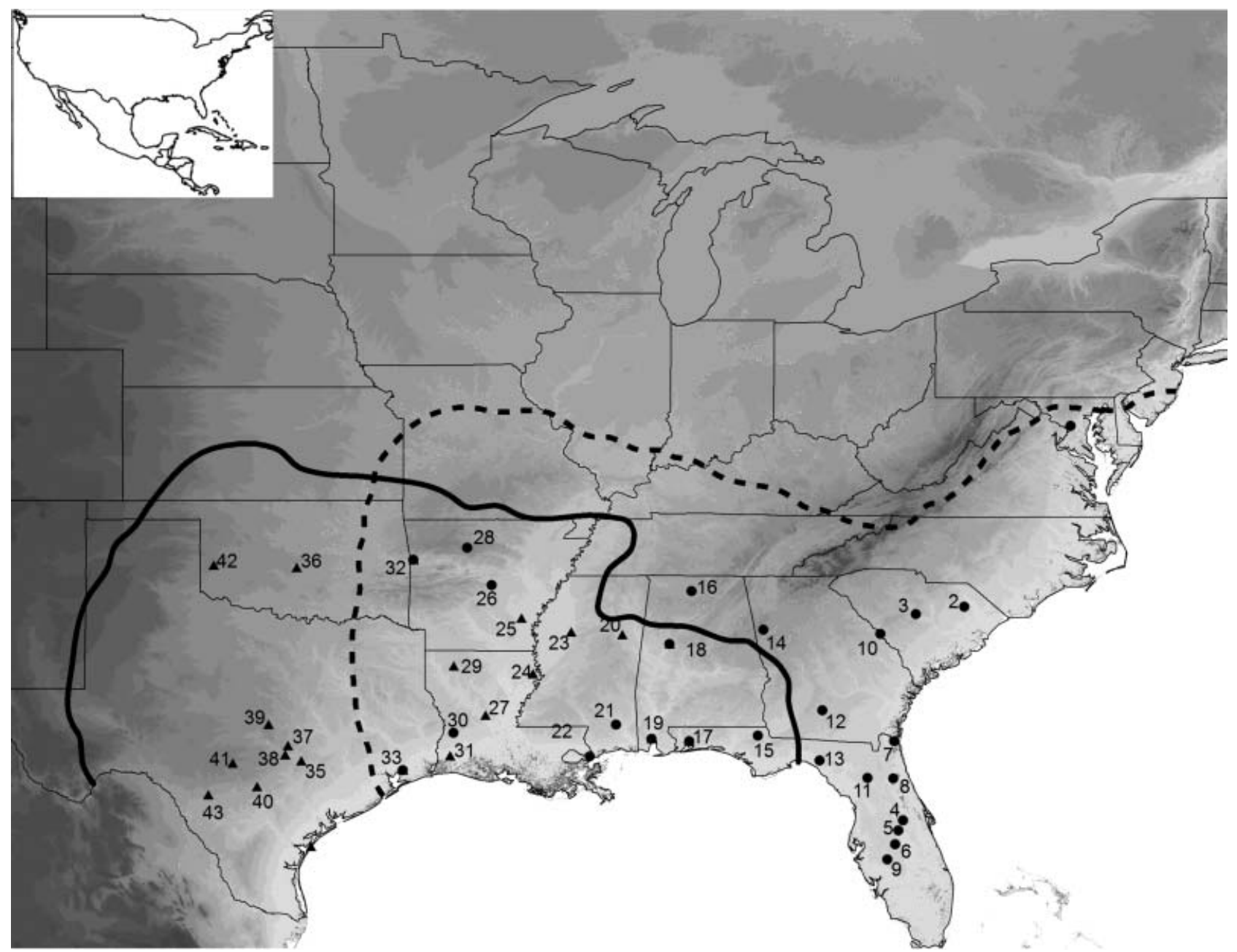

Fig. 1 Distribution of sampled populations (Gryllus texensis and G. rubens populations identified by triangles and circles, respectively; see Appendix for further details), and approximate range of G. texensis and G. rubens (delimited with solid and dashed line, respectively).

or as a by-product of ecological divergence (e.g. Doebeli et al. 2005; Vines \& Schluter 2006; Duffy et al. 2007; Gavrilets et al. 2007). However, understanding the geographical context of species divergence is critical to establishing what factors initiated divergence, and specifically, whether the contemporary sympatry of species faithfully reflects how the barrier evolved (Perret et al. 2007).

Phylogeographical study provides the context for deciphering that geographical history (Avise 2000), but the evaluation of alternative explanations for observed patterns of genetic variation requires a framework where the impact of different processes can be considered (Knowles 2004; Petit 2008). This task becomes especially challenging for recent divergence (Wakeley 2003), for which a pattern of incomplete lineage sorting might reflect the retention of ancestral polymorphism or gene flow (e.g. Kliman et al. 2000; Knowles 2001; Masta \& Maddison 2002; Buckley et al. 2006; Carstens \& Knowles 2007; Linnen \& Farrell 2007;
Peters et al. 2007; Richards \& Knowles 2007), and statistical approaches for directly computing the likelihood of these alternative scenarios (e.g. Hey 2005) are rendered unsuitable by their simplifying assumptions (Voight et al. 2005; Fagundes et al. 2007; Knowles \& Carstens 2007; Leaché et al. 2007).

Here, we use molecular data to address the biogeography of speciation in a cryptic pair of sister species of field crickets, Gryllus rubens and G. texensis. These crickets are distributed across the southern US gulf states, with G. rubens ranging from Florida and the southern Atlantic states westward to eastern Texas, and G. texensis ranging from central-western Texas eastward across the southern gulf states to far western Florida (Fig. 1). Thus, each species is broadly sympatric from western Florida to eastern Texas and also has a sizable area of allopatry. Prior work with these species has revealed (i) morphological divergence in females but not males (Gray et al. 2001); (ii) strong divergence in the longrange male calling song used to attract females for mating 
(Walker 1998, 2000; Gray \& Cade 2000; Izzo \& Gray 2004) with no evidence of reproductive character displacement (Gray \& Cade 2000; Izzo \& Gray 2004); (iii) female preference for conspecific calling song and for conspecific closerange courtship song (Gray \& Cade 2000; Gray 2005); and (iv) in G. texensis, heritable genetic variation in both male calling song and female preference for song, two genetically correlated traits (Gray \& Cade 2000). Such conditions are predicted to give rise to reproductive isolation via the assortative mating that results from the rapid coevolution of male signals and female preferences (Lande 1981; WestEberhard 1983; Higashi et al. 1999). Previous molecular work (Harrison 1979; Gray et al. 2006) had suggested that G. rubens harbours relatively little genetic variation, and that G. rubens and G. texensis mitochondrial DNA sequences produce a paraphyletic gene tree (based on mitochondrial sequences from a sample of 20 individuals). However, tests of the historical biogeographical context of divergence were limited by insufficient sampling. Here, we dramatically increase the scale of sampling to provide tests of (i) whether the lack of reciprocal monophyly reflects gene flow between the species; and (ii) whether the genealogical structure supports a peripatric mode of speciation involving the partitioning and retention of ancestral variation in the descendant taxa G. rubens and G. texensis. These hypotheses are tested using a combination of biogeographical analyses and coalescent simulations which we devised for exploring specific historical scenarios relevant to the origin of these taxa.

\section{Materials and methods}

\section{Collection and DNA sequencing}

Throughout the range of Gryllus texensis and G. rubens, 48 populations were sampled for a total of 177 individuals from 25 populations of $G$. rubens and 188 individuals from 23 populations of $G$. texensis (Appendix). Species identity was confirmed by analysis of male calling song (for male specimens) or by a combination of female ovipositor length and analysis of the calling songs of laboratory reared sons (for female specimens). Together these characters are diagnostic of species identity with little to no overlap (Gray \& Cade 2000; Gray et al. 2001; Izzo \& Gray 2004). A 724 bp fragment of the mitochondrial gene Cytochrome Oxidase C subunit I (COI) was amplified using primers C1-J-2183 and TL2-N-3014 (Simon et al. 1994). Amplification was by Polymerase Chain Reaction (30 cycles, annealing temperature $52 \mathrm{C}$ ). Negative controls were employed with each reaction. Sequencing was done on an ABI Prism 377 DNA Sequencer platform with BigDye version 3.1 chemistry. Consensus sequences for each sample were obtained by manual alignment of forward and reverse sequences using BioEdit (Hall 1999).

\section{Data analyses}

Standard measures of population genetic diversity were performed with programs DNASP (Rozas et al. 2003), including measures of haplotype diversity, the average number of pairwise differences per nucleotide site, $\pi$ (Nei 1987) and Tajima's D as a measure of historical demography assuming COI is evolving neutrally (Tajima 1989). The population structure within each species was examined using the IBD (isolation by distance) program (Jensen et al. 2005). A maximum likelihood gene tree was generated using PAUP* $4.0 \mathrm{~b} 10$ with midpoint rooting (Swofford 2002) with the PaupUp graphical interface (Calendini \& Martin 2005). An analysis of molecular variance (AMOVA) using ARLEQUIN (Schneider et al. 2000) was used to estimate genetic differentiation, including the proportion of genetic variance attributable to different hierarchical levels (i.e. between species, within species, between populations and within populations).

To investigate gene flow between the species, populations were designated as either sympatric or allopatric according to collection location. The amount of genetic divergence ( $D$; average number of substitutions per site) between allopatric and sympatric populations was calculated with DNASP (Rozas et al. 2003). If gene flow contributed to the distribution of G. rubens among G. texensis haplotypes in the gene tree, then genetic distance between allopatric $G$. texensis and $G$. rubens would be expected to be greater than sympatric G. texensis and G. rubens (i.e. gene flow would erode any genetic differences in sympatry, whereas genetic differences would be maintained in allopatry where there is no opportunity for gene flow). An AMOva was also used to determine whether geography contributed significantly to patterns of genetic differentiation, i.e. we used an AMOva with three levels: (i) between allopatric and sympatric groups; (ii) within groups between populations; and (iii) within populations.

For recently diverged species, shared polymorphism might result from ancestral lineage sorting or gene flow. While these two factors might in principle be distinguished with a robust estimate of migration, in our study, the complexities of the species history precluded such an approach [i.e. the data did not fit the assumptions of the population genetic models employed in the program IM (Hey 2005), e.g. lack of convergence of the posterior probability distributions indicated that migration estimates were not reliable for this dataset; nor were estimates of the time of divergence]. Instead, we employed coalescent simulations to explore whether the structure in the mitochondrial gene tree reflects the biogeography of species divergence. Specifically, we used two separate analyses to test whether (i) the differences in the levels of lineage sorting observed between G. rubens and each of two genetic clusters within G. texensis (referred to here after as G. texensis I and G. texensis II - see Fig. 2); and (ii) the specific genealogical structure 

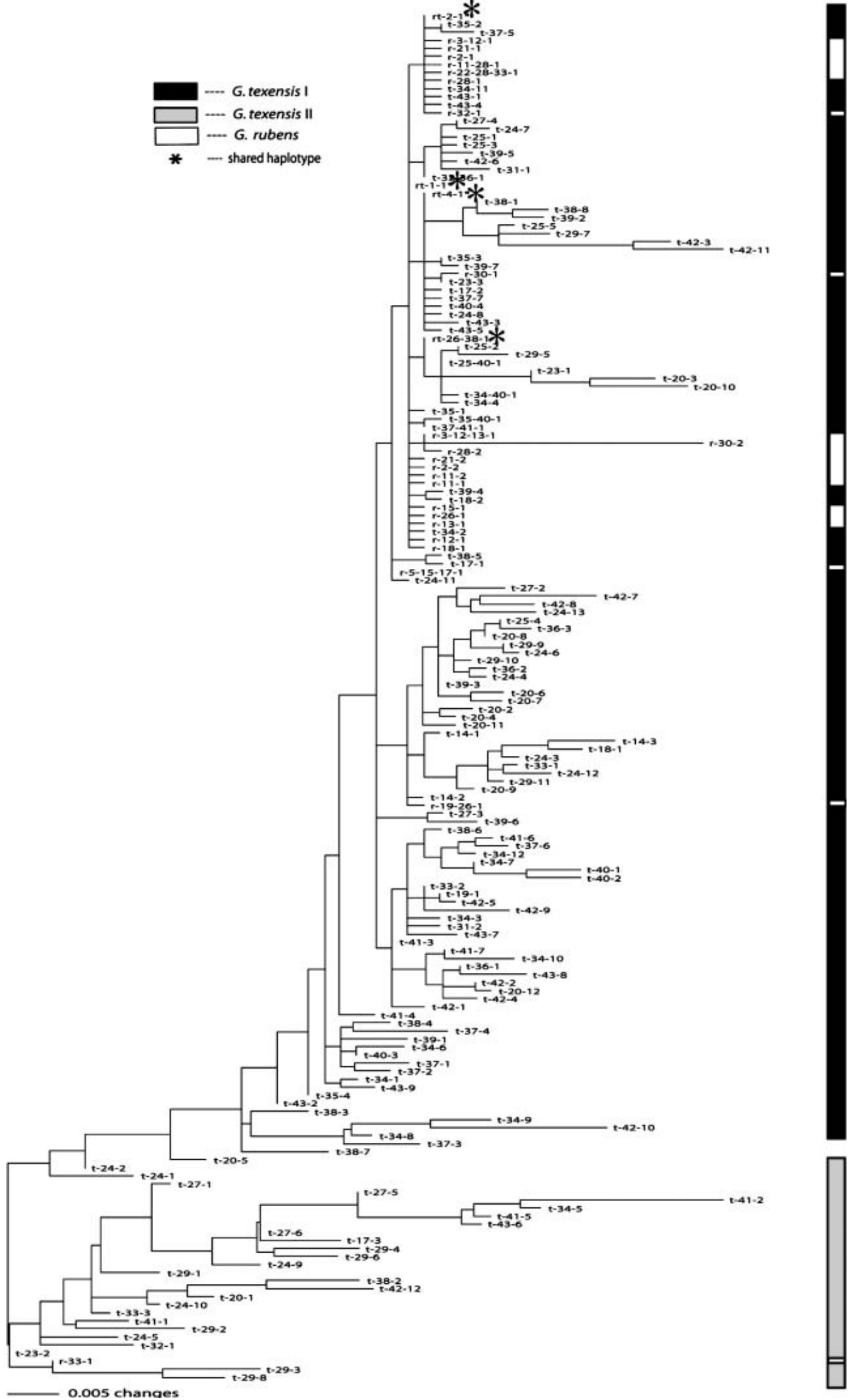

(C) 2008 The Authors

Journal compilation @ 2008 Blackwell Publishing Ltd 
within G. texensis I and G. texensis II was informative about how the species diverged. We use different summary statistics, each summarizing different aspects of genetic variation in the data, to explore the history of divergence of the species. While summary statistics do not utilize fully all the information contained in DNA sequences, they nonetheless provide a computationally tractable framework with demonstrated utility for exploring demographic and biogeographical scenarios (Knowles \& Maddison 2002; Voight et al. 2005; Hickerson et al. 2006; Fagundes et al. 2007). We use a variety of summary statistics (described in detail in the following sections), each summarizing different aspects of genetic variation in the data, to maximize the information content for the given data (multiple summaries of the data capture more information than any single summary statistic).

\section{Calculation and evaluation of the summary statistics $d w_{I I} / d w_{I}$ and $e x_{I I} / e x_{I}$}

Coalescent simulations and summary statistics were used to determine whether the unusual genetic structure within G. texensis - two genetic clusters: one with comb-like structure and the other with long external branches - was consistent with a single panmictic population that was suggested by the geographical overlap of individuals from the two genetic groups (i.e. G. texensis I and G. texensis II, Fig. 2). Genealogies were simulated using the program MS (Hudson 2002). For each simulated genealogy, the average of pairwise distances within clusters $-d w_{I}$ and $d w_{I I}$ for cluster I and cluster II, respectively (Fig. 3) - and the ratio $\left(d w_{I I} / d w_{I}\right)$ were calculated. Since this ratio might be affected by how many haplotypes are distributed in two clusters, the analyses were constrained to simulated genealogies with similar proportions of haplotypes as observed in the empirical data (i.e. 24 haplotypes in the smaller cluster), where the two genetic clusters were identified using a root that corresponded to the deepest coalescent time between lineages, and the larger of the two groups was designated as cluster I (as observed in the empirical data); because of the correspondence between

Fig. 2 Gene tree of COI alleles from Gryllus rubens and G. texensis estimated by maximum likelihood, with midpoint rooting and a model of evolution estimated from the data $(\mathrm{HKY}+\mathrm{I}+\Gamma$ : $\pi_{\mathrm{A}}=0.314, \quad \pi_{\mathrm{C}}=0.219, \quad \pi_{\mathrm{G}}=0.136, \quad \pi_{\mathrm{T}}=0.331 ; \quad t i / t v=6.35 ;$ PINV $=0.769 ; \alpha=0.155)$. The differently coloured vertical bars indicate the location of alleles from G. rubens and G. texensis clusters I and II. Each haplotype label indicates, in order: the species (marked as either $\mathrm{r}$, t or $\mathrm{rt}$ for G. rubens, G. texensis and both species, respectively), the geographical location of the haplotype identified by a population number (see Fig. 1 for distribution of populations) and the haplotype number. Haplotypes that are distributed across multiple populations are identified with each of the respective populations; three haplotypes (rt-1-1, rt-2-1 and rt4-1) occurred in numerous populations (see Appendix for details).

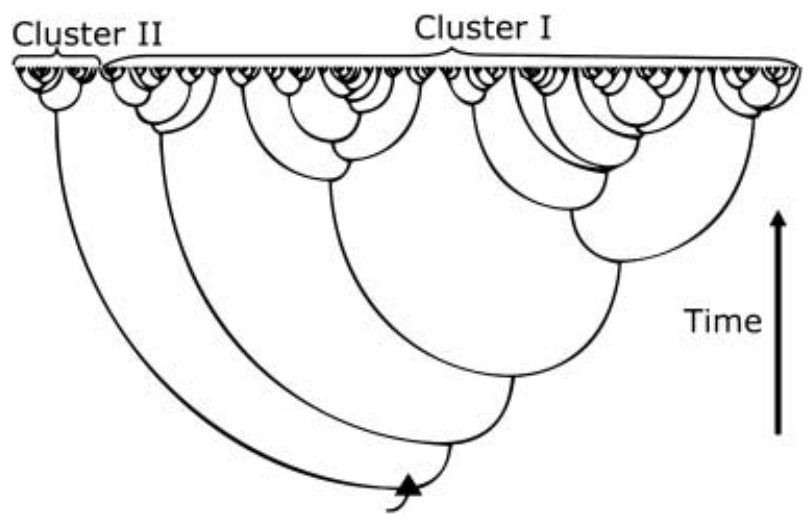

Fig. 3 An example genealogy simulated by a neutral coalescent showing the two genetic clusters (corresponding to Gryllus texensis I and II, Fig. 2) for which summary statistics were calculated (see text for details); the black triangle indicates the root of this genealogy.

the number of nucleotide differences between sequences and the order of coalescences (Takahata \& Nei 1985), this rooting scheme is consistent with the midpoint rooting used for the empirical data. The summary statistics were calculated on 1000 replicate genealogies to generate an expected distribution for the ratio $\left(d w_{I I} / d w_{I}\right)$; the hypothesis that the geographically overlapping genetic groups in G. texensis reflects a history without past structure would be rejected if the observed value (i.e. the ratio calculated for the empirical data) exceeded the values observed in $95 \%$ of the simulated data (i.e. $P<0.05$ under the null model). This test is not sensitive to assumptions about effective population size, $N_{e}$, since different population sizes affect the total depth of a gene tree (i.e. the time to coalescence) but not the shape of the genealogy: the relevant feature in testing whether the empirical data departs from expectations for the ratio $d w_{I I} / d w_{I}$.

The robustness of the conclusions to different demographic histories was also evaluated by conducting the simulations with changes in population size. Four different demographic scenarios with a range of rates of expansion and decreases in population size were considered (see Table 4 for details), and include a model of (i) exponential increase; (ii) exponential decrease, and bottlenecks involving (iii) a 10-fold and (iv) a 100-fold decrease in population size. Since the shape of genealogies generated under scenarios involving increases and decreases in population size differ from those under constant population size (Wakeley 2003), a second statistic was used to evaluate the probability of the gene-tree structure in the empirical data under models of population expansion and bottlenecks. Moreover, the use of multiple summary statistics provides more power for statistical phylogeographical tests (Knowles 2004; Voight et al. 2005). This additional statistic $\left(e x_{I I} / e x_{I}\right)$ is the ratio of average external branch lengths (i.e. the length of 


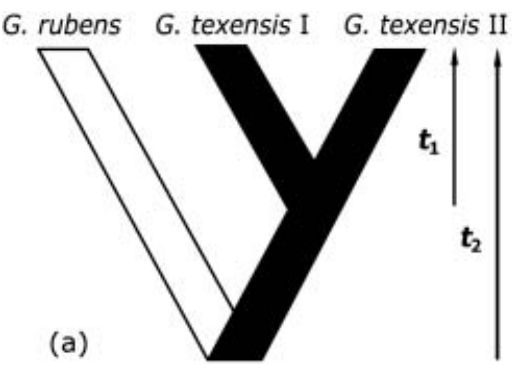

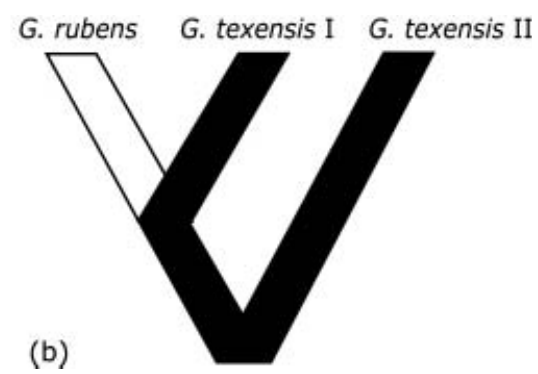

Fig. 4 The historical substructure within Gryllus texensis lineages may have (a) occurred after the divergence of G. texensis and $G$. rubens, or $(b)$ predate the divergence of G. rubens, indicating that G. rubens originated from a subset of variation in a subdivided ancestor.

Table 1 Description of genetic variation in Gryllus rubens and G. texensis. Shown from left to right are the sample sizes (n), the number of segregating sites $(\mathrm{s})$, the number of haplotypes $(\mathrm{k})$, Waterson's theta $\left(\theta_{\mathrm{w}}\right)$, nucleotide diversity $(\pi)$ (population averages are also shown in parentheses for each species), as well as the values of Tajima's D, Fu and Li's D and F (significant values are marked with an asterisk)

\begin{tabular}{|c|c|c|c|c|c|c|c|c|c|c|c|}
\hline & $n$ & $\mathrm{~s}$ & $\mathrm{k}$ & $\pi$ & $\theta$ & $\begin{array}{l}\text { Tajima's } \\
\text { D }\end{array}$ & $P$ & $\begin{array}{l}\text { Fu and } \\
\text { Li's D }^{-1}\end{array}$ & $P$ & $\begin{array}{l}\text { Fu and } \\
\text { Li's F }\end{array}$ & $P$ \\
\hline Gryllus rubens & 177 & 42 & 27 & $0.00176(0.001338)$ & $0.01009(0.00168)$ & -2.45 & $<0.01^{*}$ & -6.79 & $<0.02^{*}$ & -5.94 & $<0.02^{*}$ \\
\hline Gryllus texensis & 188 & 49 & 147 & $0.01459(0.012274)$ & $0.01188(0.0124)$ & 0.68 & $>0.10$ & -0.36 & $>0.10$ & 0.11 & $>0.10$ \\
\hline
\end{tabular}

singleton branches) for each of the two genetic clusters in G. texensis (see Fig. 3). The numbers of genealogies with both higher $d w_{I I} / d w_{I}$ and higher $e x_{I I} / e x_{I}$ than the empirical data were recorded for the 1000 genealogies simulated for each historical scenario (Table 4), where the alpha level for significance was determined with a Bonferroni correction because of the multiple tests conducted for each model.

\section{Calculation and evaluation of the summary statistics $\mathrm{d}_{r t I I} / \mathrm{d}_{\mathrm{rtI}}$}

An additional coalescent analysis was performed to address whether the genealogical split observed within G. texensis (i) occurred after the divergence between $G$. texensis and G. rubens; or (ii) may reflect a historical substructure in which $G$. rubens was derived from a subset of the ancestral variation present in G. texensis (i.e. by parapatric speciation; Harrison 1991). This test involves computing a ratio of the genetic distance between haplotypes of $G$. rubens to $G$. texensis $I\left(d_{r t I}\right)$ and $G$. texensis II $\left(d_{r t I I}\right)$. This ratio (i.e. $\left.d_{r t I I} / d_{r t I}\right)$ would be greater than one if G. texensis I shared a more recent common ancestor with $G$. rubens than $G$. texensis II (i.e. the genetic distance between G. rubens and G. texensis I haplotypes is expected to be less than that between haplotypes of G. rubens and G. texensis II; Fig. $4 \mathrm{~b}$ ), whereas $d_{r t I I} / d_{r t I}$ is expected to be equal to one, on average, if the historical substructure did not play a role in the origin of G. rubens (Fig. 4a). To determine whether a $d_{r t I I /} d_{r t I}=6.07$ (the value for the empirical data) differs significantly from what is expected if the historical substructure did not play a role in the origin of G. rubens (i.e. whether the model depicted in Fig. 4a could be statistically rejected), an expected distribution for the range of $d_{r t I I} / d_{r t I}$ values was generated from simulated data that takes into account the variance on the expectation arising from the stochasticity of genetic drift. The sample sizes used in the coalescent simulations matched those from the empirical gene tree (i.e. 177, 164 and 24 for G. rubens, G. texensis I and G. texensis II, respectively), and the population sizes were all scaled to the same value given similar estimates of $\theta$ of the three populations (Table 1 ). Without a reliable estimate of when the substructure occurred ( $t_{1}$ in Fig. $\left.4 \mathrm{a}\right)$, a conservative test with $t_{1}=t_{2}$ was used; this test of the null hypothesis is conservative because $d_{r t I}$ and $d_{r t I I}$ is expected to be more similar (i.e. $d_{r t I I} / d_{r t I}$ will approach one) as the time of divergence between the two G. texensis lineages from a common ancestor is shorter (i.e. $t_{1}<t_{2}$, Fig. 4a).

Given that G. rubens showed the genetic signature of population expansion (Table 1), the coalescent simulations were conducted for both constant and changing population sizes for G. rubens. Specifically, a model of exponential population growth was considered $\left(N_{t}=N_{e} e^{-\alpha t / 4 N e}\right.$, where $N_{t}$ is the population size $t$ generations ago and $N_{e}$ is the current population size) with rates of change $\alpha=1, \alpha=4$ and $\alpha=7$. The robustness of these results were examined over a range of differing divergence times. One-thousand genealogies each were simulated under a range of divergence times of $0.5 N_{e}$ to $4 N_{e}$ at 0.5 intervals; only relatively recent divergence times were considered since they are the conditions in which nonmonophyly of the species is expected. With an $N_{e}$ of $5 \times 10^{5}$, this translates into divergence times ranging from $0.25 \mathrm{Ma}$ to $2 \mathrm{Ma}$, with one generation per year. It is worth noting that these conditions also encompass a range of different population sizes, for a given divergence time (measured in $\mathrm{N}$ generations). For example, the results also 
Table 2 Analysis of molecular variance (AMOvA) of the data of the two species. Populations are grouped by species, and F-statistics are computed from haplotype frequency

\begin{tabular}{|c|c|c|c|c|c|c|}
\hline Source of Variation & d.f. & Sum of squares & Variance components & $F$-statistics & $\%$ total & $P$-value \\
\hline Among species & 1 & 9.341 & 0.048 & $F_{c t}=0.10$ & 10.22 & $<0.0001$ \\
\hline \multicolumn{7}{|l|}{ Among populations } \\
\hline Within species & 46 & 22.242 & 0.009 & $F_{\mathrm{sc}}=0.02$ & 1.90 & $<0.0001$ \\
\hline Within populations & 317 & 131.985 & 0.416 & $F_{\mathrm{st}}^{\mathrm{sc}}=0.12$ & 87.88 & $<0.0001$ \\
\hline Total & 364 & 163.567 & 0.4738 & & & \\
\hline
\end{tabular}

scale to a population size that ranges from 250000 to 2 million for a divergence time of $0.5 \mathrm{Ma}$.

\section{Results}

\section{Nucleotide polymorphism}

Of the 365 sequenced individuals, 170 haplotypes were identified: 27 haplotypes from the 177 individuals of Gryllus rubens and 164 haplotypes from the 188 individuals of G. texensis sampled (Table 1). An Amova detected significant divergence between species (Table 2). The estimated gene tree suggested the species are not reciprocally monophyletic (Fig. 2), and two unusual features characterize the gene tree. First, there were two genetic clusters within G. texensis that differ in structure; namely a portion of the G. texensis I cluster included a comb-like section with very closely related haplotypes compared to the relatively longer internal branches of G. texensis II (Fig. 2). Second, most of the G. rubens haplotypes were nested within $G$. texensis, but were primarily limited to just the G. texensis I cluster (all but one of the G. rubens haplotypes that nested within $G$. texensis occured within the $G$. texensis I cluster). This structure may reflect the geography of divergence in which $G$. rubens was derived from a subset of a G. texensis-like ancestor (see Fig. 4) or may reflect gene flow between $G$. rubens and $G$. texensis (see results for each hypothesis below).

With respect to the demographic history of each species, there was no evidence indicating that $G$. texensis had experienced a recent expansion (Table 1), contrasting with the demographic history of G. rubens. Likewise, there was no relationship between the genetic distance and the geographical distribution of individuals in G. texensis, whereas significant isolation by distance was detected in G. rubens $[r=0.243, P<0.005$; the isolation-by-distance (IBD) test $]$. Despite these apparent differences in the demographic history between $G$. rubens and $G$. texensis, estimates of genetic diversity were similar between the species based on $\pi$ and $\theta$ (Table 1), indicating similar effective population sizes (i.e. $\pi$ and $\theta=4 N_{e} \mu$; Tajima 1983); population-level estimates of diversity did differ between G. texensis and G. rubens, possibly reflecting the demographic expansion detected in
G. rubens (Table 1). This genetic signature of population growth in G. rubens was incorporated into the coalescent simulations to avoid misinterpretations based on inappropriate assumptions about constant population size, if $G$. rubens had indeed undergone a change in population size (for completeness, the possibility of changes in the population size of G. texensis was also considered, Table 4). While it is not possible to definitively rule out a selective sweep as causing the significant negative Tajima's $D$ value (Table 1 ), the context for such selection being limited to just one of these two species is not obvious, especially given their geographical overlap in large portions of their ranges (Fig. 1) and ecological similarity.

\section{Tests of gene flow between species}

Two separate biogeographical analyses indicate that recent gene flow is most likely not the underlying cause for the lack of reciprocal monophyly of G. rubens and G. texensis. First, if gene flow would be homogenizing G. texensis I and G. rubens, G. texensis I (but not G. texensis II) was expected to be co-distributed with G. rubens, since the G. texensis II cluster was generally distinct from G. rubens (i.e. haplotype mixing occured between G. rubens and G. texensis I; Fig. 2). However, the individuals from the two G. texensis genetic clusters broadly overlapped geographically. Moreover, there was no significant differentiation between sympatric and allopatric G. texensis (Table 3) as expected if the genetic composition of $G$. texensis I reflected gene flow with $G$. rubens. Comparison of the genetic distance between $G$. rubens and sympatric vs. allopatric $G$. texensis also showed a pattern contrary to that expected under a hypothesis of introgressive gene flow. If gene flow was the underlying cause for the lack of reciprocal monophyly, the genetic distance between sympatric G. rubens and G. texensis should have been smaller than the genetic distance between sympatric $G$. rubens and allopatric $G$. texensis. In our data, however, the former was significantly larger than the later $(0.0129$ vs. $0.0099, P<0.01$, Z-test). In summary, each of the tests - the geographical distribution of haplotypes, the genetic variation within the two G. texensis clusters, and the distances between G. rubens and sympatric vs. allopatric G. texensis - indicated that recent 
Table 3 Analysis of molecular variance (AMOva) of Gryllus texensis with sympatry vs. allopatry of G. texensis and G. rubens used to group populations (i.e. the within groups term)

\begin{tabular}{|c|c|c|c|c|c|c|}
\hline & & $\begin{array}{l}\text { Sum of } \\
\text { squares }\end{array}$ & $\begin{array}{l}\text { Variance } \\
\text { components }\end{array}$ & & & \\
\hline Source of variation & d.f. & & & F-statistics & $\%$ total & $P$-value \\
\hline $\begin{array}{l}\text { Among sympatric vs. allopatric G. texensis } \\
\text { Among populations }\end{array}$ & 1 & 0.537 & 0.00014 & $F_{\mathrm{ct}}=0.00029$ & 0.03 & $>0.291$ \\
\hline Within groups & 21 & 10.818 & 0.00313 & $F_{\mathrm{sc}}=0.00633$ & 0.63 & $>0.0635$ \\
\hline Within populations & 165 & 80.911 & 0.49037 & $F_{\mathrm{st}}=0.00662$ & 99.34 & $<0.0635$ \\
\hline Total & 187 & 92.266 & 0.49364 & & & \\
\hline
\end{tabular}

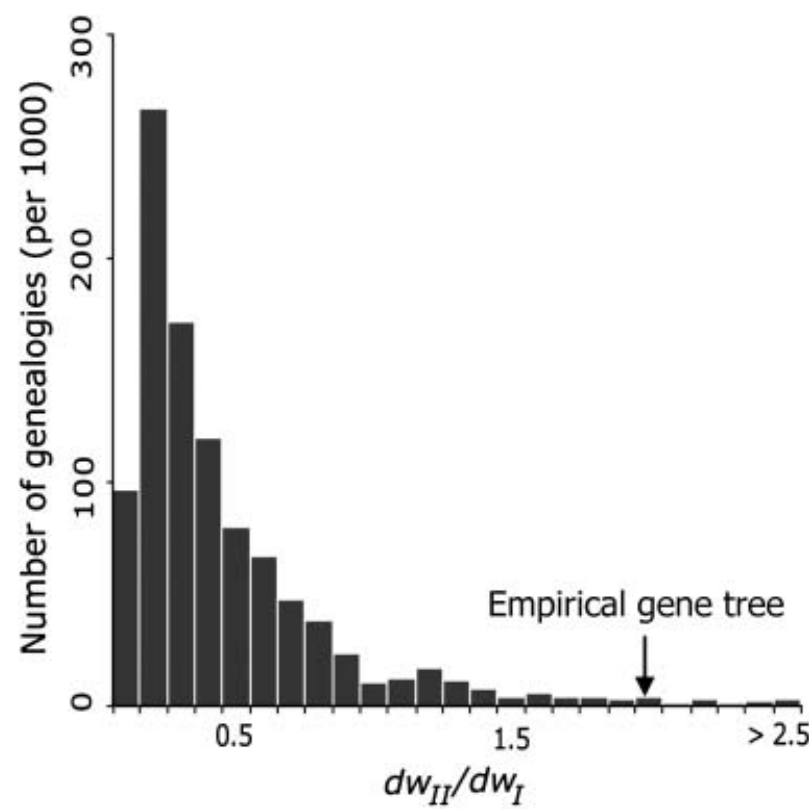

Fig. 5 Frequency distribution of $d w_{I /} / d w_{I}$ generated by a single lineage model in Gryllus texensis, where $d w_{I}$ and $d w_{I I}$ are the average pairwise distances within genetic clusters I and II (see Fig. 3). Note that the deviation of the expected distribution from a general expectation of 1 is because the test involved simulated genealogies where the distribution of haplotype numbers between the two genetic clusters also matched the empirical data.

gene flow is not a likely explanation for the lack of reciprocal monophyly between the species.

Tests of whether the gene-tree structure reflects the biogeography of species divergence

To determine whether the genealogical structure of two genetic clusters within G. texensis (i.e. G. texensis I and G. texensis II) is indicative of ancestral substructure, as opposed to a single species lineage, coalescent simulations were used to evaluate the probability of observing a ratio of $d w_{I I} / d w_{I}$ being equal to the observed empirical ratio of average pairwise distance between cluster I and II (see Fig. 3). Out of 1000 simulated genealogies with the same distribution of haplotypes across two clusters, less than $5 \%$ $(P=0.009)$ of the genealogies exhibited a $d w_{I I} / d w_{I}$ equal to the observed empirical ratio of 2.05 (Fig. 5), indicating that the genealogical structure was inconsistent with the unstructured species lineage. Coalescent simulations also confirmed that these results were generally robust to changes in population size (even though there was no significant genetic signature of population expansion in G. texensis, Table 1). The probability of observing a gene tree with the structure seen in the empirical data was very low under both models of exponential increase and decrease, as well as population bottlenecks (Table 4). A few of the models could not be rejected after adjusting the level of significance for multiple comparisons involving different rates of expansion or different times for the bottleneck based on a characterization of the gene tree involving just one summary statistic (i.e. $d w_{I I} / d w_{I}$ ). However, when multiple aspects of the gene-tree structure were considered jointly (i.e. $d w_{I I} / d w_{I}$ and $e x_{I I} / e x_{I}$ ), every one of the different scenarios of population change could be rejected significantly - that is, less than $1.3 \%$ of the genealogies exhibited characteristics observed in the empirical data (i.e. $d w_{I I} /$ $d w_{I} \geq 2.05$ and $e x_{I I} / e x_{I} \geq 2.59$; Table 4$)$. These results all indicate that it is highly unlikely that the two genetic clusters observed in G. texensis could have been derived from an unstructured species lineage, suggesting instead that, despite the contemporary overlap of G. texensis I and G. texensis II, the $G$. texensis lineage was subdivided in the past.

To determine whether such historical substructure might have played a role in speciation (Fig. 4), the timing of the origin of this substructure relative to the origin of $G$. texensis was investigated with coalescent simulations. The observed average genetic distance between $G$. rubens and G. texensis I, $d_{r t t}$ relative to that between haplotypes of $G$. rubens and $G$. texensis II, $d_{r t I I}$, was significantly greater than the null expectation as generated from the coalescent simulations (Fig. 6). This suggests that the structure in the observed gene tree (Fig. 2) is more consistent with a history 
Table 4 Test of whether the genealogical structure observed in Gryllus texensis (Fig. 2) is probable under different models of population size change. These models include: (a) a constant population size, (b) population expansion with differing amounts of size change (i.e. different $\alpha$-values, under a model of exponential change $N_{t}=N_{e} e^{-\alpha t / 4 N e}$, where $N_{t}$ is the population size $t$ generations ago and $N_{e}$ is the current population size), (c) exponential decreases in population size with different rates of decrease (i.e. different $\alpha$-values; a constant the population size was assumed prior to $16 N_{e}$ generations to avoid the problem of infinite time waiting for lineage coalescence), and a population bottleneck in which the contemporary population is either (d) 10 times or (e) 100 times smaller than the ancestral population size, for a range of different bottleneck times $(t)$. The data are not consistent with most models (i.e. the values for the simulated data are higher than those for the empirical data, specifically $d w_{I I} / d w_{I}=2.05$ and $\left.e x_{I I} / e x_{I}=2.59\right)$. Those models that can be statistically rejected are shown in bold, after a Bonferroni correction for multiplests for each model (i.e. $P<0.025)$.

\begin{tabular}{|c|c|c|}
\hline Demographic models & $d w_{I I} / d w_{I}$ & $d w_{I I} / d w_{I}$ and $e x_{I I} / e x_{I}$ \\
\hline (a) Constant population size & 0.009 & 0.001 \\
\hline \multicolumn{3}{|l|}{ (b) Exponential change on population size expansion } \\
\hline$\alpha=0.5$ & 0.008 & 0.003 \\
\hline$\alpha=1$ & 0.004 & 0.001 \\
\hline$\alpha=4$ & 0.003 & 0.001 \\
\hline$\alpha=7$ & 0.001 & 0.000 \\
\hline \multicolumn{3}{|l|}{ (c) Exponential decline in population size } \\
\hline$\alpha=-0.5$ & 0.012 & 0.003 \\
\hline$\alpha=-1$ & 0.020 & 0.006 \\
\hline$\alpha=-4$ & 0.072 & 0.013 \\
\hline$\alpha=-7$ & 0.044 & 0.006 \\
\hline \multicolumn{3}{|l|}{ (d) 10-fold decrease in population size } \\
\hline$t=0.5 N_{e}$ & 0.043 & 0.008 \\
\hline$t=1 N_{e}^{e}$ & 0.058 & 0.007 \\
\hline$t=2 N_{e}^{e}$ & 0.023 & 0.004 \\
\hline$t=3 N_{e}$ & 0.014 & 0.003 \\
\hline$t=4 N_{e}^{e}$ & 0.006 & 0.001 \\
\hline \multicolumn{3}{|l|}{ (d) 100 -fold decrease in population size } \\
\hline$t=0.5 N_{e}$ & 0.030 & 0.007 \\
\hline$t=1 N_{e}^{e}$ & 0.085 & 0.013 \\
\hline$t=2 N_{e}^{e}$ & 0.053 & 0.007 \\
\hline$t=3 N_{e}$ & 0.010 & 0.003 \\
\hline$t=4 N_{e}$ & 0.013 & 0.003 \\
\hline
\end{tabular}

in which G. rubens and G. texensis I shared a more recent common ancestor (i.e. supports the model in Fig. $4 b$ ) than did G. texensis I and G. texensis II (i.e. the model in Fig. 4a was rejected). This result was consistent across the range of divergence times considered, and was robust to possible changes in population size in G. rubens (Fig. 6).

\section{Discussion}

While multiple processes might underlie the lack of reciprocal monophyly between taxa, when such messy gene trees are examined in a predictive framework, they can yield valuable insights about species divergence (Knowles 2004). In this study, the data clearly showed that Gryllus rubens and G. texensis are very closely related, corroborating behavioural data (Gray \& Cade 2000; Izzo \& Gray 2004; Gray 2005), but that they are not reciprocally monophyletic based on the mitochondrial gene tree, as suggested by previous molecular studies with limited sampling (Harrison 1979; Gray et al. 2006). However, by considering how the processes involved in speciation would affect the geographical distribution of haplotypes, as well as the patterns of relationships among haplotypes (i.e. the gene-tree structure), we were able to statistically explore different hypotheses about how divergence in these cricket species might have proceeded. The sister taxa G. rubens and G. texensis showed very different phylogeographical patterns. G. texensis had an abundance of singleton haplotypes (Table 1) and showed no evidence of IBD. G. rubens appears to have undergone a recent population expansion (Table 1) and showed significant IBD among subpopulations. While the genetic variation within G. texensis was characterized by an abundance of singleton haplotypes, the data were not consistent with a simple demographic model of expansion (i.e. nonsignificant Fu and Li's D and Tajima's D; Table 1). The coalescent simulations also indicated that an unstructured population, even considering an array of different demographic scenarios involving increases or decreases in population size, is significantly unlikely (Table 4). Instead, 


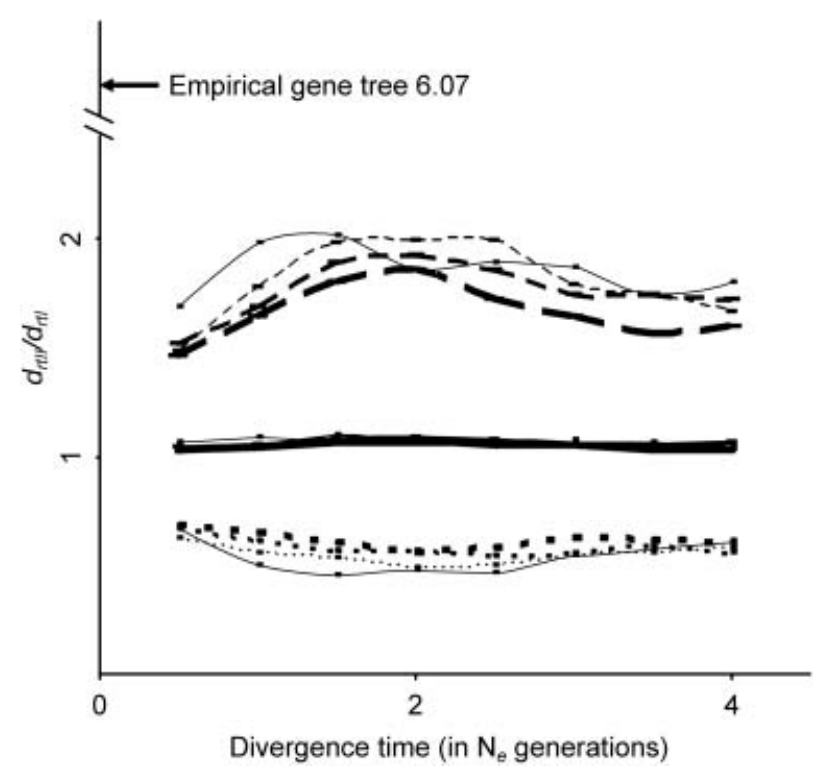

Fig. 6 The average genetic distance between Gryllus rubens and G. texensis $\mathrm{I}, d_{r t 1}$, relative to that between haplotypes of $G$. rubens and G. texensis II, $d_{r t I I}$, was significantly greater than expected under a model where the historical substructure played no role in speciation (i.e. the model in Fig. 4a can be rejected). The solid line represents the mean of $d_{r t I I} / d_{r t I}$ (i.e. the average genetic distance between $G$. rubens and $G$. texensis I, $d_{r t I}$ relative to that between haplotypes of G. rubens and G. texensis II, $\left.d_{r t I I}\right)$, at different divergence times for a range of demographic conditions. These models include a constant population size and exponential population growth for G. rubens, $N_{t}=N_{e} e^{-\alpha} t / 4 N e$, where $N_{t}$ is the population size $t$ generations ago and $N_{e}$ is the current population size; $\alpha$ represents different rates of change. The different rates of population change are identified by different line widths ranging from the thickest to thinnest lines, for $\alpha=1,4$ and 7, respectively. Note that the mean expectations (shown by solid lines) overlap between the constant population size and those involving population expansion (i.e. a $d_{r t I I} / d_{r t I}$ of approximately 1 ); the dashed lines represent the $95 \%$ confidence interval for each demographic model. The arrow indicates the $d_{r t I I} / d_{r t I}$ value calculated from empirical data.

the history of this species appears to be quite complex. G. texensis showed no significant IBD; rather, the haplotypes were distributed into two broadly distributed and geographically overlapping clusters (G. texensis I and G. texensis II; Fig. 2). Despite the co-distribution of haplotypes between the two G. texensis clusters, and their geographical overlap with haplotypes from G. rubens, the gene tree shows that all but one of the G. rubens haplotypes (including four shared haplotypes) were limited to just one lineage of $G$. texensis (i.e. the G. texensis I cluster; Fig. 2).

This complicated genealogical structure, with haplotypes of $G$. rubens mixed with haplotypes from $G$. texensis I but not $G$. texensis II, could have arisen from gene flow or reflect the incomplete sorting of gene lineages from a common ancestor. However, the series of tests used to evaluate these possibilities suggest that the polyphyletic structure of the gene tree reflects the geographical history of divergence and not of gene flow (see details below). The complexity of these species histories no doubt also contributes to a serious violation of the assumptions of the divergence models used by typical coalescent-based likelihood or Bayesian approaches for estimating population genetic parameters (reviewed in Excoffier \& Heckel 2006), thus precluding their use in this study. This unusual structure, particularly within G. texensis, motivated the use of the novel alternative analyses presented here (see also Knowles \& Maddison 2002; Fagundes et al. 2007). However, as with any statistical phylogeographical study, only a small subset of historical scenarios was evaluated because of the enormous space of potential histories (e.g. varying population sizes and migration rates that might differ between species and change among populations and over the species history), and simplifying assumptions might affect the results (Knowles \& Maddison 2002). Without additional data (i.e. multiple loci), it is also not possible to evaluate the extent to which the patterns of differentiation observed in the mitochondrial sequences are an accurate reflection of the species' histories. Despite these caveats, the approach and combination of tests that were devised identify a biologically interesting model of species divergence - namely, peripatric speciation (e.g. Harrison 1991; Knowles et al. 1999). Under this model, past geographical substructure may have contributed to the origin of the cricket species, even though such regional division is not apparent today (e.g. the two G. texensis genetic clusters are co-distributed across the species range). The implications of this model, including how these findings might motivate future potential studies, as well as supporting evidence from comparison with other taxa in the region, are discussed below.

\section{The role of historical regional substructure in species divergence}

There is no behavioural, morphological or other evidence whatsoever suggesting the existence of two cryptic species within the currently recognized G. texensis, or significant differentiation between populations of $G$. texensis that are distributed sympatrically vs. allopatrically with respect to G. rubens (Table 3). This indicates that the general lack of $G$. rubens haplotypes within the G. texensis II cluster does not reflect some differential gene flow owing to reproductive isolation. Despite a number of undescribed cryptic species within North American Gryllus (unpublished data, D. Weissman and D. Gray), the unimodal distribution of intraspecific variation in reproductive characters (e.g. song and female preference traits; Gray \& Cade 2000, 1999; Izzo \& Gray 2004) and lack of, or correspondence with, the two mitochondrial genetic clusters indicates a lack of cryptic species in G. texensis. Moreover, the statistical 
phylogeographical test, which revealed that the degree of genetic differentiation between sympatric $G$. texensis and G. rubens was greater (not smaller, as expected) than the genetic distance between allopatric $G$. texensis and $G$. rubens, also indicates that recent gene flow is not a sufficient explanation for the lack of reciprocal monophyly between the species - although low levels of past or present hybridization are certainly not precluded by these analyses.

The genealogical structure is consistent with two population lineages of $G$. texensis with incomplete sorting of ancestral polymorphisms between this subdivided ancestor and the more recently derived species $G$. rubens (Fig. 4b). The apparently large population sizes of these crickets are indeed consistent with this observation; tens or even hundreds of thousands of these crickets engage in eruptive flights every summer and fall (Cade 1979), and the total numbers of $G$. texensis could easily be several million or more (W. H. Cade, personal communication), greatly reducing the rate of lineage sorting. Furthermore, our simulations also showed support for the origination of G. rubens from one of the two ancestral lineages of $G$. texensis (Fig. 6). Such a scenario would be consistent with a geographical scenario in which proto-G. rubens became geographically isolated, perhaps in peninsular Florida during the climate-induced distributional shifts caused by the Pleistocene glacial cycles. Our data indicating recent population expansion of G. rubens combined with significant IBD further support this model. Such regional substructure has been documented in other taxa from the area, including both plants and animal species (see comparative phylogeographical review of 148 taxa, Soltis et al. 2006). In the absence of additional loci in the crickets for genetic analysis, these comparative studies identify the plausibility of the model of species divergence proposed by our study (i.e. the observed patterns of differentiation in COI are not simply a reflection of the historical dynamics of the mitochondrial genome owing to a discordance between the observed gene tree and the actual species history, Maddison 1997). Nonetheless, multilocus data are not only important for testing the proposed peripatric model of divergence, but it would also be very helpful for deriving accurate population genetic parameter estimates from coalescent-based likelihood or Bayesian approaches (reviewed in Excoffier \& Heckel 2006) and would provide a more biologically realistic model of divergence.

In contrast to the distinct biogeographical patterns that mirror these past discontinuities in many of the taxa from the general study area (e.g. regions divided by the Apalachicola River, Appalachian Mountains, Tombigbee River and the Mississippi River; reviewed in Soltis et al. 2006), no such correspondence between geography and genetic divergence was apparent in $G$. texensis. While any regional substructure that might have existed in the historical past of G. texensis (Fig. 4b) apparently has been eroded by migration, a lack of evidence for recent gene flow between sympatric G. texensis and G. rubens suggests that divergence in behavioural traits is an effective reproductive barrier (Gray \& Cade 2000; Gray 2005). However, this will need to be confirmed with additional genetic data. Interestingly, genetic evidence suggests that species boundaries are quite porous in other related and recently derived Gryllus taxa (Broughton \& Harrison 2003), suggesting that gene flow homogenizes species differences except for those characters for which divergence is maintained by selection. Further investigations into the demography of speciation of G. texensis and G. rubens should provide an important context for identifying whether the mode of speciation actually differs among these recently derived North American gryllines (i.e. divergence with or without gene flow) and what it is about the species-specific traits that confer a more (or less) effective reproductive barrier to gene flow.

\section{Acknowledgements}

We would like to thank Godfrey Hewitt and three anonymous reviewers for their helpful comments, which greatly improved the quality of the manuscript, and Amanda Zellmer for help with making the map.

\section{References}

Avise JC (2000) Phylogeography: the History and Formation of Species. Harvard University Press, Cambridge, MA.

Broughton RE, Harrison RG (2003) Nuclear gene genealogies reveal historical, demographic and selective factors associated with speciation in field crickets. Genetics, 163, 1389-1401.

Buckley T, Cordeiro M, Marshall D, Simon C (2006) Differentiating between hypotheses of lineage sorting and introgression in New Zealand alpine cicadas (Maoricicada Dugdale). Systematic Biology, 55, 411-425.

Cade WH (1979) Field cricket dispersal flights measured by crickets landing at lights. Texas Journal of Science, XXXI, 125-130.

Calendini F, Martin J-F (2005) PaupUP v1.0.2032.22590 Beta. A free graphical frontend for Paup* Dos software.

Carstens BC, Knowles LL (2007) Shifting distributions and speciation: species divergence during rapid climate change. Molecular Ecology, 16, 619-627.

Doebeli M, Dieckman U, Metz JAJ, Tautz D (2005) What we have also learned: adaptive speciation in theoretically plausible. Evolution, 59, 691-695.

Duffy S, Burch CL, Turner PE (2007) Evolution of host specificty drives reproductive isolation among RNA viruses. Evolution, 61, 2614-2622.

Excoffier L, Heckel G (2006) Computer programs for population genetics data analysis: a survival guide. Nature Review of Genetics, 7, 745-758.

Fagundes NJR, Ray N, Beaumont Met al. (2007) Statistical evaluation of alternative models of human evolution. Proceedings of the National Academy of Sciences, USA, 104, 17614-17619.

Gavrilets S, Vose A, Barluenga M et al. (2007) Case studies and 
mathematical models of ecological speciation. 1. cichlids in a crater lake. Molecular Ecology, 16, 2893-2909.

Gray DA (2005) Does courtship behavior contribute to specieslevel reproductive isolation in field crickets? Behavioral Ecology, 16, 201-206.

Gray DA, Cade WH (1999) Quantitative genetics of sexual selection in the field cricket, Gryllus integer. Evolution, 53, 848-854.

Gray DA, Cade WH (2000) Sexual selection and speciation in field crickets. Proceedings of the National Academy of Sciences, USA, 97, 14449-14454.

Gray DA, Walker TJ, Conley BE, Cade WH (2001) A morphological means of distinguishing females of the cryptic field cricket species, Gryllus rubens and G. texensis (Orthoptera: Gryllidae). Florida Entomologist, 84, 314-315.

Gray DA, Barnfield P, Seifried M, Ritchards MR (2006) Molecular divergence between Gryllus rubens and Gryllus texensis, sister species of field crickets (Orthoptera: Gryllidae). Canadian Entomologist, 138, 305-313.

Hall TA (1999) BioEdit: a user-friendly biological sequence alignment editor and analysis program for Windows 95/98/NT. Nucleic Acids Symposium Series, 41, 95-98.

Harrison RG (1979) Speciation in North American field crickets: evidence from electrophoretic comparsons. Evolution, 33, 1009 1023.

Harrison RG (1991) Molecular-changes at speciation. Annual Review of Ecology and Systematics, 22, 281-308.

Hey J (2005) The number of New World founders: a population genetic portrait of the peopling of the Americas. PLoS Biology, 36, e193.

Hickerson M, Dolman G, Mortiz C (2006) Comparative phylogeographic summary statistics for testing simultaneous vicariance. Molecular Ecology, 15, 209-223.

Higashi M, Takimoto G, Yamamura N (1999) Sympatric speciation by sexual selection. Nature, 402, 523-526.

Higgie M, Chenoweth S, Blows MW (2000) Natural selection and the reinforcement of mate recognition. Science, 290, 519-521.

Hudson RR (2002) Generating samples under a Wright-Fisher neutral model of genetic variation. Bioinformatics, 18, 337-338.

Izzo AS, Gray DA (2004) Cricket song in sympatry: species specificity of song without reproductive character displacement in Gryllus rubens. Annals of the Entomological Society of America, 97, 831-837.

Jensen JL, Bohonak AJ, Kelley ST (2005) Isolation by distance, web service. BMC Genetics, 6, 13.

Kliman RM, Andolfatto P, Coyne JA et al. (2000) The population genetics of the origin and divergence of the Drosophila simulans complex species. Genetics, 156, 1913-1931.

Knowles LL (2001) Did the Pleistocene glaciations promote divergence? Tests of explicit refugial models in montane grasshoppers. Molecular Ecology, 10, 691-701.

Knowles LL (2004) The burgeoning field of statistical phylogeography. Journal of Evolutionary Biology, 17, 1-10.

Knowles LL, Carstens BC (2007) Estimating a geographically explicit model of population divergence. Evolution, 61, 477-493.

Knowles LL, Maddison WP (2002) Statistical phylogeography. Molecular Ecology, 11, 2623-2635.

Knowles LL, Futuyma DJ, Eanes WF, Rannala B (1999) Insights into speciation mode from historical demography in the phytophagous beetle Ophraella. Evolution, 53, 1846-1856.

Lande R (1981) Models of speciation by sexual selection on polygenic traits. Proceedings of the National Academy of Sciences, USA, 78, 3721-3725.
Leaché AD, Crews SC, Hickerson MJ (2007) Two waves of diversification in mammals and reptiles of Baja California revealed by hierarchical Bayesian analysis. Biology Letters, 3, 646-650.

Linnen CR, Farrell BD (2007) Mitonuclear discordance is caused by rampant mitochondrial introgression in Neodiprion (Hymenoptera: Diprionidae) sawflies. Evolution, 61, 1417-1438.

Maddison WP (1997) Gene trees in species trees. Systematic. Biology, 46, 523-536.

Masta SE, Maddison WP (2002) Sexual selection driving diversification in jumping spiders. Proceedings of the National Academy of Sciences, USA, 99, 4442-4447.

Nei M (1987) Molecular Evoluitonary Genetics. Columbia University Press, New York.

Payne RJH, Krakauer DC (1997) Sexual selection, space and speciation. Evolution, 51, 1-9.

Perret M, Chautems A, Spichiger R et al. (2007) The geographical pattern of speciation and floral diversification in the neotropics: the tribe Sinningieae (Gesneriaceae) as a case study. Evolution, 61, 1641-4660.

Peters JL, Zhuravlev Y, Fefelov I et al. (2007) Nuclear loci and coalescent methods support ancient hybridization as cause of mitochondrial paraphyly between gadwall and falcated duck (Anas spp.). Evolution, 61, 1992-2006.

Petit RJ (2008) The coup de grace for the nested clade phylogeographic analysis? Molecular Ecology, 17, 516-518.

Richards CL, Knowles LL (2007) Tests of phenotypic and genetic concordance and their application to the conservation of Panamanian golden frogs (Anura, Bufonidae). Molecular Ecology, 16, 3119-3133.

Rozas J, Sanchez-De I, Barrio JC et al. (2003) DnaSP, DNA polymorphism analyses by the coalescent and other methods. Bioinformatics, 19, 2496-2497.

Schneider S, Roessli D, Excoffier L (2000) Arlequin: A software for population genetics data analysis. Ver 2.000. Genetics and Biometry Laboratory, Department of Anthropology, University of Geneva. http://lgb.unige.ch/arlequin/software/.

Simon C, Frati F, Beckenbach A et al. (1994) Evolution, weighting, and phylogenetic utility of mitochondrial gene sequences and a compilation of conserved polymerase chain reaction primers. Annals of the Entomological Society of America, 87, 651-701.

Soltis DE, Morris AB, McLachlan JS et al. (2006) Comparative phylogeography of unglaciated eastern North America. Molecular Ecology, 15, 4261-4293.

Swofford DL (2002) PAuP*. Phylogenetic Analysis Using Parsimony (*and Other Methods), Version 4. Sinauer Associates, Sunderland, MA.

Tajima F (1983) Evolutionary relationship of DNA sequences in finite populations. Genetics, 105, 437-460.

Tajima F (1989) Statistical method for testing the neutral mutation hypothesis by DNA polymorphism. Genetics, 123, 585-595.

Takahata N, Nei M (1985) Gene genealogy and variance of interpopulational nucleotide differences. Genetics, 110, 325-344.

Takimoto G, Higashi M, Yamamura N (2000) A deterministic genetic model for sympatric speciation by sexual selection. Evolution, 54, 1870-1881.

Turner GF, Burrows MT (1995) A model of sympatric speciation by sexual selection. Proceedings of the Royal Society of London, Series B: Biological Sciences, 260, 287-292.

Vines TH, Schluter D (2006) Strong assortative mating between allopatric sticklebacks as a by-product of adaptation to different environments. Proceedings of the Royal Society of London, Series B: Biological Sciences, 273, 911-916. 
3848 D. A. GRAY, H. HUANG and L. L. KNOWLES

Voight BF, Adams AM, Frisse LA et al. (2005) Interrogating multiple aspects of variation in a full resequencing data set to infer human population size changes. Proceedings of the National Academy of Sciences, USA, 102, 18508-18513.

Wakeley J (2003) Inferences about the structure and history of populations: coalescents and intraspecific phylogeography. In: The Evolution of Population Biology (eds Singh R, Uyenoyama M), pp. 193-215. Cambridge University Press, Cambridge.

Walker TJ (1998) Trilling field crickets in a zone of overlap (Orthoptera: Gryllidae: Gryllus). Annals of the Entomological Society of America, 91, 175-184.
Walker TJ (2000) Pulse rates in the songs of trilling field crickets (Orthoptera: Gryllidae: Gryllus). Annals of the Entomological Society of America, 93, 565-572.

West-Eberhard MJ (1983) Sexual selection, social competition, and speciation. Quarterly Review of Biology, 58, 155-182.

The authors are interested in using the geographic distribution of molecular genetic variation for the analysis of species and population history, including understanding the process of speciation. 
Appendix Samples, collection localities, and haplotype identities

\begin{tabular}{|c|c|c|c|c|c|c|}
\hline Species & Population & County & State & $\begin{array}{l}\text { Latitude } \\
\text { (degrees North) }\end{array}$ & $\begin{array}{l}\text { Longitude } \\
\text { (degrees West) }\end{array}$ & Haplotype \\
\hline Gryllus rubens & Augusta & Richmond & Georgia & 33.471 & 81.975 & rt-1-1 \\
\hline Gryllus rubens & Augusta & Richmond & Georgia & 33.471 & 81.975 & rt-1-1 \\
\hline Gryllus rubens & College Park & Prince George's & Maryland & 38.981 & 76.937 & rt-1-1 \\
\hline Gryllus rubens & College Park & Prince George's & Maryland & 38.981 & 76.937 & rt-1-1 \\
\hline Gryllus rubens & Columbia & Richland & South Carolina & 34.001 & 81.035 & rt-1-1 \\
\hline Gryllus rubens & Columbia & Richland & South Carolina & 34.001 & 81.035 & rt-1-1 \\
\hline Gryllus rubens & Columbia & Richland & South Carolina & 34.001 & 81.035 & $r-3-12-13-1$ \\
\hline Gryllus rubens & Columbia & Richland & South Carolina & 34.001 & 81.035 & rt-1-1 \\
\hline Gryllus rubens & Columbia & Richland & South Carolina & 34.001 & 81.035 & rt-2-1 \\
\hline Gryllus rubens & Columbia & Richland & South Carolina & 34.001 & 81.035 & $r-3-12-1$ \\
\hline Gryllus rubens & Columbia & Richland & South Carolina & 34.001 & 81.035 & $\mathrm{rt}-1-1^{*}$ \\
\hline Gryllus rubens & Columbia & Richland & South Carolina & 34.001 & 81.035 & rt-1-1 \\
\hline Gryllus rubens & Columbia & Richland & South Carolina & 34.001 & 81.035 & rt-2-1 \\
\hline Gryllus rubens & Columbia & Richland & South Carolina & 34.001 & 81.035 & rt-1-1 \\
\hline Gryllus rubens & Columbia & Richland & South Carolina & 34.001 & 81.035 & rt-1-1 \\
\hline Gryllus rubens & Columbia & Richland & South Carolina & 34.001 & 81.035 & rt-1-1 \\
\hline Gryllus rubens & Columbia & Richland & South Carolina & 34.001 & 81.035 & rt-1-1 \\
\hline Gryllus rubens & Columbia & Richland & South Carolina & 34.001 & 81.035 & rt-2-1 \\
\hline Gryllus rubens & Columbia & Richland & South Carolina & 34.001 & 81.035 & $\mathrm{rt}-1-1$ \\
\hline Gryllus rubens & Columbia & Richland & South Carolina & 34.001 & 81.035 & rt-1-1 \\
\hline Gryllus rubens & Columbia & Richland & South Carolina & 34.001 & 81.035 & $\mathrm{rt}-2-1^{*}$ \\
\hline Gryllus rubens & Decatur & Morgan & Alabama & 34.606 & 86.983 & $\mathrm{rt}-2-1$ \\
\hline Gryllus rubens & DeRidder & Beauregard & Louisiana & 30.846 & 93.289 & rt-4-1 \\
\hline Gryllus rubens & DeRidder & Beauregard & Louisiana & 30.846 & 93.289 & rt-1-1 \\
\hline Gryllus rubens & DeRidder & Beauregard & Louisiana & 30.846 & 93.289 & $\mathrm{r}-30-1$ \\
\hline Gryllus rubens & DeRidder & Beauregard & Louisiana & 30.846 & 93.289 & rt-2-1 \\
\hline Gryllus rubens & DeRidder & Beauregard & Louisiana & 30.846 & 93.289 & rt-2-1 \\
\hline Gryllus rubens & DeRidder & Beauregard & Louisiana & 30.846 & 93.289 & $r-30-2$ \\
\hline Gryllus rubens & DeSoto National Forest & Perry & Mississippi & 31.067 & 88.983 & rt-1-1 \\
\hline Gryllus rubens & DeSoto National Forest & Perry & Mississippi & 31.067 & 88.983 & rt-2-1 \\
\hline Gryllus rubens & DeSoto National Forest & Perry & Mississippi & 31.067 & 88.983 & rt-2-1 \\
\hline Gryllus rubens & DeSoto National Forest & Perry & Mississippi & 31.067 & 88.983 & rt-2-1 \\
\hline Gryllus rubens & DeSoto National Forest & Perry & Mississippi & 31.067 & 88.983 & $\mathrm{r}-21-1$ \\
\hline Gryllus rubens & DeSoto National Forest & Perry & Mississippi & 31.067 & 88.983 & rt-1-1 \\
\hline Gryllus rubens & DeSoto National Forest & Perry & Mississippi & 31.067 & 88.983 & $\mathrm{r}-21-2$ \\
\hline Gryllus rubens & DeSoto National Forest & Perry & Mississippi & 31.067 & 88.983 & rt-2-1 \\
\hline Gryllus rubens & DeSoto National Forest & Perry & Mississippi & 31.067 & 88.983 & rt-1-1 \\
\hline Gryllus rubens & Florence & Florence & South Carolina & 34.195 & 79.763 & rt-2-1 \\
\hline Gryllus rubens & Florence & Florence & South Carolina & 34.195 & 79.763 & $\mathrm{r}-2-1$ \\
\hline Gryllus rubens & Florence & Florence & South Carolina & 34.195 & 79.763 & rt-2-1 \\
\hline Gryllus rubens & Florence & Florence & South Carolina & 34.195 & 79.763 & $\mathrm{r}-2-2$ \\
\hline Gryllus rubens & Florence & Florence & South Carolina & 34.195 & 79.763 & rt-1-1 \\
\hline Gryllus rubens & Florence & Florence & South Carolina & 34.195 & 79.763 & rt-1-1 \\
\hline Gryllus rubens & Florence & Florence & South Carolina & 34.195 & 79.763 & rt-1-1 \\
\hline Gryllus rubens & Florence & Florence & South Carolina & 34.195 & 79.763 & rt-1-1 \\
\hline Gryllus rubens & Florence & Florence & South Carolina & 34.195 & 79.763 & rt-1-1 \\
\hline Gryllus rubens & Gainesville & Alachua & Florida & 29.651 & 82.325 & $\mathrm{r}-11-1$ \\
\hline Gryllus rubens & Gainesville & Alachua & Florida & 29.651 & 82.325 & rt-2-1 \\
\hline Gryllus rubens & Gainesville & Alachua & Florida & 29.651 & 82.325 & rt-1-1 \\
\hline Gryllus rubens & Gainesville & Alachua & Florida & 29.651 & 82.325 & rt-1-1 \\
\hline Gryllus rubens & Gainesville & Alachua & Florida & 29.651 & 82.325 & rt-2-1 \\
\hline Gryllus rubens & Gainesville & Alachua & Florida & 29.651 & 82.325 & rt-2-1 \\
\hline Gryllus rubens & Gainesville & Alachua & Florida & 29.651 & 82.325 & $\mathrm{rt}-2-1$ \\
\hline Gryllus rubens & Gainesville & Alachua & Florida & 29.651 & 82.325 & $\mathrm{r}-11-2$ \\
\hline Gryllus rubens & Gainesville & Alachua & Florida & 29.651 & 82.325 & rt-1-1 \\
\hline Gryllus rubens & Gainesville & Alachua & Florida & 29.651 & 82.325 & rt-1-1 \\
\hline
\end{tabular}




\begin{tabular}{|c|c|c|c|c|c|c|}
\hline Species & Population & County & State & $\begin{array}{l}\text { Latitude } \\
\text { (degrees North) }\end{array}$ & $\begin{array}{l}\text { Longitude } \\
\text { (degrees West) }\end{array}$ & Haplotype \\
\hline Gryllus rubens & Gainesville & Alachua & Florida & 29.651 & 82.325 & rt-1-1 \\
\hline Gryllus rubens & Gainesville & Alachua & Florida & 29.651 & 82.325 & rt-1-1 \\
\hline Gryllus rubens & Gainesville & Alachua & Florida & 29.651 & 82.325 & rt-1-1 \\
\hline Gryllus rubens & Gainesville & Alachua & Florida & 29.651 & 82.325 & rt-1-1 \\
\hline Gryllus rubens & Gainesville & Alachua & Florida & 29.651 & 82.325 & $\mathrm{r}-11-28-1$ \\
\hline Gryllus rubens & Gainesville & Alachua & Florida & 29.651 & 82.325 & $\mathrm{rt}-2-1$ \\
\hline Gryllus rubens & Gainesville & Alachua & Florida & 29.651 & 82.325 & rt-1-1 \\
\hline Gryllus rubens & Gainesville & Alachua & Florida & 29.651 & 82.325 & rt-1-1 \\
\hline Gryllus rubens & Gainesville & Alachua & Florida & 29.651 & 82.325 & rt-1-1 \\
\hline Gryllus rubens & Hankamer & Chambers & Texas & 29.858 & 94.627 & $r-33-1$ \\
\hline Gryllus rubens & Hankamer & Chambers & Texas & 29.858 & 94.627 & rt- $4-1^{*}$ \\
\hline Gryllus rubens & Hankamer & Chambers & Texas & 29.858 & 94.627 & rt-2-1 \\
\hline Gryllus rubens & Hankamer & Chambers & Texas & 29.858 & 94.627 & rt-1-1 \\
\hline Gryllus rubens & Hankamer & Chambers & Texas & 29.858 & 94.627 & rt-1-1 \\
\hline Gryllus rubens & Hankamer & Chambers & Texas & 29.858 & 94.627 & rt-2-1 \\
\hline Gryllus rubens & Hankamer & Chambers & Texas & 29.858 & 94.627 & rt-2-1 \\
\hline Gryllus rubens & Hankamer & Chambers & Texas & 29.858 & 94.627 & rt-1-1 \\
\hline Gryllus rubens & Hankamer & Chambers & Texas & 29.858 & 94.627 & rt-4-1 \\
\hline Gryllus rubens & Hankamer & Chambers & Texas & 29.858 & 94.627 & $\mathrm{r}-33-1$ \\
\hline Gryllus rubens & Hankamer & Chambers & Texas & 29.858 & 94.627 & rt-2-1 \\
\hline Gryllus rubens & Hankamer & Chambers & Texas & 29.858 & 94.627 & rt-2-1 \\
\hline Gryllus rubens & Lake Wales $($ HWY60 × 27) & Polk & Florida & 27.901 & 81.586 & rt-1-1 \\
\hline Gryllus rubens & Lake Wales $(\mathrm{HWY} 60 \times 27)$ & Polk & Florida & 27.901 & 81.586 & rt-1-1 \\
\hline Gryllus rubens & Lake Wales $(\mathrm{HWY} 60 \times 27)$ & Polk & Florida & 27.901 & 81.586 & rt-4-1 \\
\hline Gryllus rubens & Lake Wales $($ HWY60 × 27) & Polk & Florida & 27.901 & 81.586 & rt-2-1 \\
\hline Gryllus rubens & Lake Wales $(\mathrm{HWY} 60 \times 27)$ & Polk & Florida & 27.901 & 81.586 & rt-1-1 \\
\hline Gryllus rubens & Intercession City & Osceola & Florida & 28.262 & 81.508 & r-5-15-17-1 \\
\hline Gryllus rubens & Intercession City & Osceola & Florida & 28.262 & 81.508 & rt-1-1 \\
\hline Gryllus rubens & Intercession City & Osceola & Florida & 28.262 & 81.508 & rt-1-1 \\
\hline Gryllus rubens & Intercession City & Osceola & Florida & 28.262 & 81.508 & rt-1-1 \\
\hline Gryllus rubens & Kisatchie National Forest & Winn & Louisiana & 35.753 & 92.917 & $\mathrm{r}-28-1$ \\
\hline Gryllus rubens & Kisatchie National Forest & Winn & Louisiana & 35.753 & 92.917 & rt-2-1 \\
\hline Gryllus rubens & Kisatchie National Forest & Winn & Louisiana & 35.753 & 92.917 & rt-1-1 \\
\hline Gryllus rubens & Kisatchie National Forest & Winn & Louisiana & 35.753 & 92.917 & $\mathrm{r}-11-28-1$ \\
\hline Gryllus rubens & Kisatchie National Forest & Winn & Louisiana & 35.753 & 92.917 & $\mathrm{r}-33-1$ \\
\hline Gryllus rubens & Kisatchie National Forest & Winn & Louisiana & 35.753 & 92.917 & rt-2-1 \\
\hline Gryllus rubens & Kisatchie National Forest & Winn & Louisiana & 35.753 & 92.917 & rt-1-1 \\
\hline Gryllus rubens & Kisatchie National Forest & Winn & Louisiana & 35.753 & 92.917 & rt-2-1 \\
\hline Gryllus rubens & Kisatchie National Forest & Winn & Louisiana & 35.753 & 92.917 & rt-2-1 \\
\hline Gryllus rubens & Kisatchie National Forest & Winn & Louisiana & 35.753 & 92.917 & $\mathrm{rt}-2-1$ \\
\hline Gryllus rubens & Kisatchie National Forest & Winn & Louisiana & 35.753 & 92.917 & $\mathrm{r}-28-2$ \\
\hline Gryllus rubens & Kisatchie National Forest & Winn & Louisiana & 35.753 & 92.917 & $\mathrm{r}-33-1$ \\
\hline Gryllus rubens & Marianna & Jackson & Florida & 30.774 & 85.227 & rt-2-1 \\
\hline Gryllus rubens & Marianna & Jackson & Florida & 30.774 & 85.227 & rt-1-1 \\
\hline Gryllus rubens & Marianna & Jackson & Florida & 30.774 & 85.227 & rt-1-1 \\
\hline Gryllus rubens & Marianna & Jackson & Florida & 30.774 & 85.227 & rt-2-1 \\
\hline Gryllus rubens & Marianna & Jackson & Florida & 30.774 & 85.227 & rt-1-1 \\
\hline Gryllus rubens & Marianna & Jackson & Florida & 30.774 & 85.227 & rt-1-1 \\
\hline Gryllus rubens & Marianna & Jackson & Florida & 30.774 & 85.227 & r-5-15-17-1 \\
\hline Gryllus rubens & Marianna & Jackson & Florida & 30.774 & 85.227 & rt-1-1 \\
\hline Gryllus rubens & Marianna & Jackson & Florida & 30.774 & 85.227 & $\mathrm{r}-15-1$ \\
\hline Gryllus rubens & Marianna & Jackson & Florida & 30.774 & 85.227 & rt-1-1 \\
\hline Gryllus rubens & Milton-Pensacola & Santa Rosa & Florida & 30.632 & 87.040 & rt-2-1 \\
\hline Gryllus rubens & Milton-Pensacola & Santa Rosa & Florida & 30.632 & 87.040 & r-5-15-17-1 \\
\hline Gryllus rubens & Milton-Pensacola & Santa Rosa & Florida & 30.632 & 87.040 & rt-2-1 \\
\hline Gryllus rubens & Mobile & Mobile & Alabama & 30.694 & 88.043 & $\mathrm{r}-19-26-1$ \\
\hline Gryllus rubens & North Little Rock & Pulaski & Arkansas & 34.769 & 92.267 & $\mathrm{r}-19-26-1$ \\
\hline
\end{tabular}


Appendix Continued

\begin{tabular}{|c|c|c|c|c|c|c|}
\hline Species & Population & County & State & $\begin{array}{l}\text { Latitude } \\
\text { (degrees North) }\end{array}$ & $\begin{array}{l}\text { Longitude } \\
\text { (degrees West) }\end{array}$ & Haplotype \\
\hline Gryllus rubens & North Little Rock & Pulaski & Arkansas & 34.769 & 92.267 & rt-1-1 \\
\hline Gryllus rubens & North Little Rock & Pulaski & Arkansas & 34.769 & 92.267 & rt-4-1 \\
\hline Gryllus rubens & North Little Rock & Pulaski & Arkansas & 34.769 & 92.267 & $\mathrm{r}-26-1$ \\
\hline Gryllus rubens & North Little Rock & Pulaski & Arkansas & 34.769 & 92.267 & $\mathrm{r}-26-1$ \\
\hline Gryllus rubens & North Little Rock & Pulaski & Arkansas & 34.769 & 92.267 & rt-1-1 \\
\hline Gryllus rubens & North Little Rock & Pulaski & Arkansas & 34.769 & 92.267 & rt-4-1 \\
\hline Gryllus rubens & North Little Rock & Pulaski & Arkansas & 34.769 & 92.267 & rt-2-1 \\
\hline Gryllus rubens & Orlando & Orange & Florida & 28.538 & 81.379 & $\mathrm{rt}-2-1$ \\
\hline Gryllus rubens & Orlando & Orange & Florida & 28.538 & 81.379 & rt-1-1 \\
\hline Gryllus rubens & Orlando & Orange & Florida & 28.538 & 81.379 & rt-4-1 \\
\hline Gryllus rubens & Orlando & Orange & Florida & 28.538 & 81.379 & $\mathrm{rt}-1-1$ \\
\hline Gryllus rubens & Palatka & Putnam & Florida & 29.648 & 81.638 & rt-2-1 \\
\hline Gryllus rubens & Palatka & Putnam & Florida & 29.648 & 81.638 & rt-1-1 \\
\hline Gryllus rubens & Palatka & Putnam & Florida & 29.648 & 81.638 & rt-1-1 \\
\hline Gryllus rubens & Palatka & Putnam & Florida & 29.648 & 81.638 & rt-1-1 \\
\hline Gryllus rubens & Milton-Pensacola & Santa Rosa & Florida & 30.632 & 87.040 & $\mathrm{r}-15-1$ \\
\hline Gryllus rubens & Milton-Pensacola & Santa Rosa & Florida & 30.632 & 87.040 & $\mathrm{rt}-1-1$ \\
\hline Gryllus rubens & Perry & Taylor & Florida & 30.117 & 83.582 & $\mathrm{rt}-2-1$ \\
\hline Gryllus rubens & Perry & Taylor & Florida & 30.117 & 83.582 & rt-2-1 \\
\hline Gryllus rubens & Perry & Taylor & Florida & 30.117 & 83.582 & rt-2-1 \\
\hline Gryllus rubens & Perry & Taylor & Florida & 30.117 & 83.582 & $\mathrm{r}-13-1$ \\
\hline Gryllus rubens & Perry & Taylor & Florida & 30.117 & 83.582 & $\mathrm{r}-3-12-13-1$ \\
\hline Gryllus rubens & Perry & Taylor & Florida & 30.117 & 83.582 & rt-1-1 \\
\hline Gryllus rubens & Perry & Taylor & Florida & 30.117 & 83.582 & $\mathrm{rt}-1-1$ \\
\hline Gryllus rubens & Perry & Taylor & Florida & 30.117 & 83.582 & rt-1-1 \\
\hline Gryllus rubens & Tifton & Tift & Georgia & 31.450 & 83.509 & $\mathrm{r}-12-1$ \\
\hline Gryllus rubens & Tifton & Tift & Georgia & 31.450 & 83.509 & rt-2-1 \\
\hline Gryllus rubens & Tifton & Tift & Georgia & 31.450 & 83.509 & $\mathrm{rt}-2-1$ \\
\hline Gryllus rubens & Tifton & Tift & Georgia & 31.450 & 83.509 & rt-2-1 \\
\hline Gryllus rubens & Tifton & Tift & Georgia & 31.450 & 83.509 & rt-1-1 \\
\hline Gryllus rubens & Tifton & Tift & Georgia & 31.450 & 83.509 & $r-3-12-13-1$ \\
\hline Gryllus rubens & Tifton & Tift & Georgia & 31.450 & 83.509 & rt-2-1 \\
\hline Gryllus rubens & Tifton & Tift & Georgia & 31.450 & 83.509 & $r-3-12-1$ \\
\hline Gryllus rubens & Tifton & Tift & Georgia & 31.450 & 83.509 & rt-1-1 \\
\hline Gryllus rubens & Tifton & Tift & Georgia & 31.450 & 83.509 & rt-1-1 \\
\hline Gryllus rubens & Tifton & Tift & Georgia & 31.450 & 83.509 & $\mathrm{rt}-2-1$ \\
\hline Gryllus rubens & Tifton & Tift & Georgia & 31.450 & 83.509 & rt-2-1 \\
\hline Gryllus rubens & Tifton & Tift & Georgia & 31.450 & 83.509 & rt-1-1 \\
\hline Gryllus rubens & Tifton & Tift & Georgia & 31.450 & 83.509 & $\mathrm{rt}-2-1$ \\
\hline Gryllus rubens & Tifton & Tift & Georgia & 31.450 & 83.509 & rt-1-1 \\
\hline Gryllus rubens & Tifton & Tift & Georgia & 31.450 & 83.509 & rt-1-1 \\
\hline Gryllus rubens & Tifton & Tift & Georgia & 31.450 & 83.509 & $\mathrm{rt}-2-1$ \\
\hline Gryllus rubens & Tuscaloosa & Tuscaloosa & Alabama & 33.210 & 87.569 & rt-1-1 \\
\hline Gryllus rubens & Tuscaloosa & Tuscaloosa & Alabama & 33.210 & 87.569 & rt-1-1 \\
\hline Gryllus rubens & Tuscaloosa & Tuscaloosa & Alabama & 33.210 & 87.569 & $\mathrm{rt}-1-1$ \\
\hline Gryllus rubens & Tuscaloosa & Tuscaloosa & Alabama & 33.210 & 87.569 & rt-1-1 \\
\hline Gryllus rubens & Tuscaloosa & Tuscaloosa & Alabama & 33.210 & 87.569 & $\mathrm{rt}-2-1$ \\
\hline Gryllus rubens & Tuscaloosa & Tuscaloosa & Alabama & 33.210 & 87.569 & rt-1-1 \\
\hline Gryllus rubens & Tuscaloosa & Tuscaloosa & Alabama & 33.210 & 87.569 & rt-1-1 \\
\hline Gryllus rubens & Tuscaloosa & Tuscaloosa & Alabama & 33.210 & 87.569 & $\mathrm{r}-18-1$ \\
\hline Gryllus rubens & Tuscaloosa & Tuscaloosa & Alabama & 33.210 & 87.569 & $\mathrm{r}-18-1$ \\
\hline Gryllus rubens & Tuscaloosa & Tuscaloosa & Alabama & 33.210 & 87.569 & rt-1-1 \\
\hline Gryllus rubens & Tuscaloosa & Tuscaloosa & Alabama & 33.210 & 87.569 & $\mathrm{rt}-1-1$ \\
\hline Gryllus rubens & Van Buren & Crawford & Arkansas & 35.437 & 94.348 & $\mathrm{rt}-2-1$ \\
\hline Gryllus rubens & Van Buren & Crawford & Arkansas & 35.437 & 94.348 & rt-4-1 \\
\hline Gryllus rubens & Van Buren & Crawford & Arkansas & 35.437 & 94.348 & $\mathrm{rt}-2-1$ \\
\hline Gryllus rubens & Van Buren & Crawford & Arkansas & 35.437 & 94.348 & $\mathrm{r}-32-1$ \\
\hline
\end{tabular}

(C) 2008 The Authors

Journal compilation @ 2008 Blackwell Publishing Ltd 
Appendix Continued

\begin{tabular}{|c|c|c|c|c|c|c|}
\hline Species & Population & County & State & $\begin{array}{l}\text { Latitude } \\
\text { (degrees North) }\end{array}$ & $\begin{array}{l}\text { Longitude } \\
\text { (degrees West) }\end{array}$ & Haplotype \\
\hline Gryllus rubens & White Kitchen & St. Tammany & Louisiana & 30.228 & 89.677 & $\mathrm{rt}-2-1$ \\
\hline Gryllus rubens & White Kitchen & St. Tammany & Louisiana & 30.228 & 89.677 & $r-22-28-33-1$ \\
\hline Gryllus rubens & White Kitchen & St. Tammany & Louisiana & 30.228 & 89.677 & rt-2-1 \\
\hline Gryllus rubens & White Kitchen & St. Tammany & Louisiana & 30.228 & 89.677 & rt-2-1 \\
\hline Gryllus rubens & White Kitchen & St. Tammany & Louisiana & 30.228 & 89.677 & rt-2-1 \\
\hline Gryllus rubens & Yulee & Nassau & Florida & 30.632 & 81.607 & rt-1-1 \\
\hline Gryllus rubens & Zolfo Springs & Hardee & Florida & 27.493 & 81.796 & rt-1-1 \\
\hline Gryllus texensis & Alexandria & Rapides & Louisiana & 31.311 & 92.445 & $\mathrm{t}-27-1$ \\
\hline Gryllus texensis & Alexandria & Rapides & Louisiana & 31.311 & 92.445 & $t-27-2$ \\
\hline Gryllus texensis & Alexandria & Rapides & Louisiana & 31.311 & 92.445 & $t-27-3$ \\
\hline Gryllus texensis & Alexandria & Rapides & Louisiana & 31.311 & 92.445 & $t-27-4$ \\
\hline Gryllus texensis & Alexandria & Rapides & Louisiana & 31.311 & 92.445 & $\mathrm{t}-27-5$ \\
\hline Gryllus texensis & Alexandria & Rapides & Louisiana & 31.311 & 92.445 & $t-27-6$ \\
\hline Gryllus texensis & Alexandria & Rapides & Louisiana & 31.311 & 92.445 & rt-2-1 \\
\hline Gryllus texensis & Austin & Travis & Texas & 30.267 & 97.743 & $t-38-1$ \\
\hline Gryllus texensis & Austin & Travis & Texas & 30.267 & 97.743 & rt-1-1 \\
\hline Gryllus texensis & Austin & Travis & Texas & 30.267 & 97.743 & $t-38-2$ \\
\hline Gryllus texensis & Austin & Travis & Texas & 30.267 & 97.743 & $t-38-3$ \\
\hline Gryllus texensis & Austin & Travis & Texas & 30.267 & 97.743 & rt-26-38-1 \\
\hline Gryllus texensis & Austin & Travis & Texas & 30.267 & 97.743 & rt-4-1 \\
\hline Gryllus texensis & Austin & Travis & Texas & 30.267 & 97.743 & rt-1-1 \\
\hline Gryllus texensis & Austin & Travis & Texas & 30.267 & 97.743 & $t-38-4$ \\
\hline Gryllus texensis & Austin & Travis & Texas & 30.267 & 97.743 & $t-38-5$ \\
\hline Gryllus texensis & Austin & Travis & Texas & 30.267 & 97.743 & $t-38-6$ \\
\hline Gryllus texensis & Austin & Travis & Texas & 30.267 & 97.743 & $\mathrm{t}-38-7$ \\
\hline Gryllus texensis & Austin & Travis & Texas & 30.267 & 97.743 & $t-38-8$ \\
\hline Gryllus texensis & Bastrop & Bastrop & Texas & 30.110 & 97.315 & $t-35-1$ \\
\hline Gryllus texensis & Bastrop & Bastrop & Texas & 30.110 & 97.315 & $t-35-2$ \\
\hline Gryllus texensis & Bastrop & Bastrop & Texas & 30.110 & 97.315 & $t-35-3$ \\
\hline Gryllus texensis & Bastrop & Bastrop & Texas & 30.110 & 97.315 & $t-35-4$ \\
\hline Gryllus texensis & Bastrop & Bastrop & Texas & 30.110 & 97.315 & $t-35-40-1$ \\
\hline Gryllus texensis & Bastrop & Bastrop & Texas & 30.110 & 97.315 & rt-4-1 \\
\hline Gryllus texensis & Carrollton & Carroll & Georgia & 33.580 & 85.077 & $\mathrm{t}-14-1$ \\
\hline Gryllus texensis & Carrollton & Carroll & Georgia & 33.580 & 85.077 & $t-14-2$ \\
\hline Gryllus texensis & Carrollton & Carroll & Georgia & 33.580 & 85.077 & $t-14-3$ \\
\hline Gryllus texensis & Dumas & Desha & Arkansas & 33.887 & 91.492 & $t-25-1$ \\
\hline Gryllus texensis & Dumas & Desha & Arkansas & 33.887 & 91.492 & $t-25-2$ \\
\hline Gryllus texensis & Dumas & Desha & Arkansas & 33.887 & 91.492 & $t-25-3$ \\
\hline Gryllus texensis & Dumas & Desha & Arkansas & 33.887 & 91.492 & $\mathrm{t}-25-4$ \\
\hline Gryllus texensis & Dumas & Desha & Arkansas & 33.887 & 91.492 & rt-2-1 \\
\hline Gryllus texensis & Dumas & Desha & Arkansas & 33.887 & 91.492 & $\mathrm{t}-25-40-1$ \\
\hline Gryllus texensis & Dumas & Desha & Arkansas & 33.887 & 91.492 & $t-25-5$ \\
\hline Gryllus texensis & Greenwood & Leflore & Mississippi & 33.516 & 90.179 & $t-23-1$ \\
\hline Gryllus texensis & Greenwood & Leflore & Mississippi & 33.516 & 90.179 & $t-23-2$ \\
\hline Gryllus texensis & Greenwood & Leflore & Mississippi & 33.516 & 90.179 & $t-23-3$ \\
\hline Gryllus texensis & Hankamer & Chambers & Texas & 29.858 & 94.627 & $t-33-1$ \\
\hline Gryllus texensis & Hankamer & Chambers & Texas & 29.858 & 94.627 & rt-1-1 \\
\hline Gryllus texensis & Hankamer & Chambers & Texas & 29.858 & 94.627 & $t-33-2$ \\
\hline Gryllus texensis & Hankamer & Chambers & Texas & 29.858 & 94.627 & rt-1-1 \\
\hline Gryllus texensis & Hankamer & Chambers & Texas & 29.858 & 94.627 & $t-33-3$ \\
\hline Gryllus texensis & Hankamer & Chambers & Texas & 29.858 & 94.627 & rt-1-1 \\
\hline Gryllus texensis & Kerrville & Kerr & Texas & 30.047 & 99.140 & $\mathrm{t}-41-1$ \\
\hline Gryllus texensis & Kerrville & Kerr & Texas & 30.047 & 99.140 & $\mathrm{t}-41-2$ \\
\hline Gryllus texensis & Kerrville & Kerr & Texas & 30.047 & 99.140 & $t-41-3$ \\
\hline Gryllus texensis & Kerrville & Kerr & Texas & 30.047 & 99.140 & $\mathrm{t}-41-4$ \\
\hline Gryllus texensis & Kerrville & Kerr & Texas & 30.047 & 99.140 & $\mathrm{t}-41-5$ \\
\hline Gryllus texensis & Kerrville & Kerr & Texas & 30.047 & 99.140 & $\mathrm{t}-41-5$ \\
\hline
\end{tabular}


Appendix Continued

\begin{tabular}{|c|c|c|c|c|c|c|}
\hline Species & Population & County & State & $\begin{array}{l}\text { Latitude } \\
\text { (degrees North) }\end{array}$ & $\begin{array}{l}\text { Longitude } \\
\text { (degrees West) }\end{array}$ & Haplotype \\
\hline Gryllus texensis & Kerrville & Kerr & Texas & 30.047 & 99.140 & $\mathrm{t}-41-6$ \\
\hline Gryllus texensis & Kerrville & Kerr & Texas & 30.047 & 99.140 & rt-2-1 \\
\hline Gryllus texensis & Kerrville & Kerr & Texas & 30.047 & 99.140 & $\mathrm{t}-41-7$ \\
\hline Gryllus texensis & Lampasas & Lampasas & Texas & 31.064 & 98.181 & rt-1-1 \\
\hline Gryllus texensis & Lampasas & Lampasas & Texas & 31.064 & 98.181 & $\mathrm{rt}-1-1$ \\
\hline Gryllus texensis & Lampasas & Lampasas & Texas & 31.064 & 98.181 & $t-39-1$ \\
\hline Gryllus texensis & Lampasas & Lampasas & Texas & 31.064 & 98.181 & $\mathrm{t}-39-2$ \\
\hline Gryllus texensis & Lampasas & Lampasas & Texas & 31.064 & 98.181 & $\mathrm{t}-39-3$ \\
\hline Gryllus texensis & Lampasas & Lampasas & Texas & 31.064 & 98.181 & rt-1-1 \\
\hline Gryllus texensis & Lampasas & Lampasas & Texas & 31.064 & 98.181 & $\mathrm{t}-39-4$ \\
\hline Gryllus texensis & Lampasas & Lampasas & Texas & 31.064 & 98.181 & $t-39-5$ \\
\hline Gryllus texensis & Lampasas & Lampasas & Texas & 31.064 & 98.181 & rt-2-1 \\
\hline Gryllus texensis & Lampasas & Lampasas & Texas & 31.064 & 98.181 & $t-39-6$ \\
\hline Gryllus texensis & Lampasas & Lampasas & Texas & 31.064 & 98.181 & $\mathrm{t}-39-7$ \\
\hline Gryllus texensis & Milton-Pensacola & Santa Rosa & Florida & 30.632 & 87.040 & $\mathrm{t}-17-1$ \\
\hline Gryllus texensis & Minden & Webster & Louisiana & 32.615 & 93.287 & $t-29-1$ \\
\hline Gryllus texensis & Minden & Webster & Louisiana & 32.615 & 93.287 & $\mathrm{t}-29-2$ \\
\hline Gryllus texensis & Minden & Webster & Louisiana & 32.615 & 93.287 & $t-29-3$ \\
\hline Gryllus texensis & Minden & Webster & Louisiana & 32.615 & 93.287 & $\mathrm{t}-29-4$ \\
\hline Gryllus texensis & Minden & Webster & Louisiana & 32.615 & 93.287 & $\mathrm{t}-29-5$ \\
\hline Gryllus texensis & Minden & Webster & Louisiana & 32.615 & 93.287 & $t-29-6$ \\
\hline Gryllus texensis & Minden & Webster & Louisiana & 32.615 & 93.287 & $\mathrm{t}-29-7$ \\
\hline Gryllus texensis & Minden & Webster & Louisiana & 32.615 & 93.287 & $\mathrm{t}-29-8$ \\
\hline Gryllus texensis & Minden & Webster & Louisiana & 32.615 & 93.287 & $t-29-9$ \\
\hline Gryllus texensis & Minden & Webster & Louisiana & 32.615 & 93.287 & $t-29-10$ \\
\hline Gryllus texensis & Minden & Webster & Louisiana & 32.615 & 93.287 & $\mathrm{t}-29-11$ \\
\hline Gryllus texensis & Mobile & Mobile & Alabama & 30.694 & 88.043 & $\mathrm{t}-19-1$ \\
\hline Gryllus texensis & Norman & Cleveland & Oklahoma & 35.223 & 97.439 & rt-1-1 \\
\hline Gryllus texensis & Norman & Cleveland & Oklahoma & 35.223 & 97.439 & $t-36-1$ \\
\hline Gryllus texensis & Norman & Cleveland & Oklahoma & 35.223 & 97.439 & $t-36-2$ \\
\hline Gryllus texensis & Norman & Cleveland & Oklahoma & 35.223 & 97.439 & $t-36-3$ \\
\hline Gryllus texensis & Norman & Cleveland & Oklahoma & 35.223 & 97.439 & rt-1-1 \\
\hline Gryllus texensis & Norman & Cleveland & Oklahoma & 35.223 & 97.439 & $t-36-3$ \\
\hline Gryllus texensis & Milton-Pensacola & Santa Rosa & Florida & 30.632 & 87.040 & $\mathrm{t}-17-2$ \\
\hline Gryllus texensis & Milton-Pensacola & Santa Rosa & Florida & 30.632 & 87.040 & $\mathrm{t}-17-3$ \\
\hline Gryllus texensis & Port Aransas & Nueces & Texas & 27.834 & 97.061 & $\mathrm{t}-34-9$ \\
\hline Gryllus texensis & Port Aransas & Nueces & Texas & 27.834 & 97.061 & $\mathrm{rt}-2-1$ \\
\hline Gryllus texensis & Port Aransas & Nueces & Texas & 27.834 & 97.061 & $t-34-10$ \\
\hline Gryllus texensis & Port Aransas & Nueces & Texas & 27.834 & 97.061 & $t-34-11$ \\
\hline Gryllus texensis & Port Aransas & Nueces & Texas & 27.834 & 97.061 & $t-34-12$ \\
\hline Gryllus texensis & Port Aransas & Nueces & Texas & 27.834 & 97.061 & $\mathrm{t}-34-40-1$ \\
\hline Gryllus texensis & Port Aransas & Nueces & Texas & 27.834 & 97.061 & $t-34-1$ \\
\hline Gryllus texensis & Port Aransas & Nueces & Texas & 27.834 & 97.061 & $\mathrm{t}-34-2$ \\
\hline Gryllus texensis & Port Aransas & Nueces & Texas & 27.834 & 97.061 & $\mathrm{t}-34-3$ \\
\hline Gryllus texensis & Port Aransas & Nueces & Texas & 27.834 & 97.061 & $t-34-4$ \\
\hline Gryllus texensis & Port Aransas & Nueces & Texas & 27.834 & 97.061 & $\mathrm{t}-34-5$ \\
\hline Gryllus texensis & Port Aransas & Nueces & Texas & 27.834 & 97.061 & $\mathrm{rt}-2-1$ \\
\hline Gryllus texensis & Port Aransas & Nueces & Texas & 27.834 & 97.061 & rt-4-1 \\
\hline Gryllus texensis & Port Aransas & Nueces & Texas & 27.834 & 97.061 & $t-34-6$ \\
\hline Gryllus texensis & Port Aransas & Nueces & Texas & 27.834 & 97.061 & rt-4-1 \\
\hline Gryllus texensis & Port Aransas & Nueces & Texas & 27.834 & 97.061 & $\mathrm{t}-34-7$ \\
\hline Gryllus texensis & Port Aransas & Nueces & Texas & 27.834 & 97.061 & $\mathrm{t}-34-8$ \\
\hline Gryllus texensis & Port Aransas & Nueces & Texas & 27.834 & 97.061 & rt-2-1 \\
\hline Gryllus texensis & Round Rock & Williamson & Texas & 30.508 & 97.679 & $\mathrm{t}-37-1$ \\
\hline Gryllus texensis & Round Rock & Williamson & Texas & 30.508 & 97.679 & $\mathrm{t}-37-2$ \\
\hline Gryllus texensis & Round Rock & Williamson & Texas & 30.508 & 97.679 & $\mathrm{t}-37-3$ \\
\hline Gryllus texensis & Round Rock & Williamson & Texas & 30.508 & 97.679 & $\mathrm{t}-37-4$ \\
\hline
\end{tabular}

(C) 2008 The Authors

Journal compilation @ 2008 Blackwell Publishing Ltd 
Appendix Continued

\begin{tabular}{|c|c|c|c|c|c|c|}
\hline Species & Population & County & State & $\begin{array}{l}\text { Latitude } \\
\text { (degrees North) }\end{array}$ & $\begin{array}{l}\text { Longitude } \\
\text { (degrees West) }\end{array}$ & Haplotype \\
\hline Gryllus texensis & Round Rock & Williamson & Texas & 30.508 & 97.679 & $t-37-5$ \\
\hline Gryllus texensis & Round Rock & Williamson & Texas & 30.508 & 97.679 & $t-37-6$ \\
\hline Gryllus texensis & Round Rock & Williamson & Texas & 30.508 & 97.679 & rt- $4-1$ \\
\hline Gryllus texensis & Round Rock & Williamson & Texas & 30.508 & 97.679 & $\mathrm{t}-37-41-1$ \\
\hline Gryllus texensis & Round Rock & Williamson & Texas & 30.508 & 97.679 & $\mathrm{t}-37-7$ \\
\hline Gryllus texensis & Round Rock & Williamson & Texas & 30.508 & 97.679 & rt-1-1 \\
\hline Gryllus texensis & Round Rock & Williamson & Texas & 30.508 & 97.679 & rt-1-1 \\
\hline Gryllus texensis & San Antonio & Bexar & Texas & 29.424 & 98.493 & $t-40-1$ \\
\hline Gryllus texensis & San Antonio & Bexar & Texas & 29.424 & 98.493 & $t-25-40-1$ \\
\hline Gryllus texensis & San Antonio & Bexar & Texas & 29.424 & 98.493 & $\mathrm{t}-40-2$ \\
\hline Gryllus texensis & San Antonio & Bexar & Texas & 29.424 & 98.493 & $t-40-3$ \\
\hline Gryllus texensis & San Antonio & Bexar & Texas & 29.424 & 98.493 & rt-1-1 \\
\hline Gryllus texensis & San Antonio & Bexar & Texas & 29.424 & 98.493 & $\mathrm{t}-40-4$ \\
\hline Gryllus texensis & San Antonio & Bexar & Texas & 29.424 & 98.493 & $t-35-40-1$ \\
\hline Gryllus texensis & San Antonio & Bexar & Texas & 29.424 & 98.493 & rt-4-1 \\
\hline Gryllus texensis & San Antonio & Bexar & Texas & 29.424 & 98.493 & rt-2-1 \\
\hline Gryllus texensis & San Antonio & Bexar & Texas & 29.424 & 98.493 & $\mathrm{t}-34-40-1$ \\
\hline Gryllus texensis & Sayre & Beckham & Oklahoma & 35.291 & 99.640 & $\mathrm{t}-42-1$ \\
\hline Gryllus texensis & Sayre & Beckham & Oklahoma & 35.291 & 99.640 & $\mathrm{t}-42-2$ \\
\hline Gryllus texensis & Sayre & Beckham & Oklahoma & 35.291 & 99.640 & $t-42-3$ \\
\hline Gryllus texensis & Sayre & Beckham & Oklahoma & 35.291 & 99.640 & $t-42-4$ \\
\hline Gryllus texensis & Sayre & Beckham & Oklahoma & 35.291 & 99.640 & $\mathrm{t}-42-5$ \\
\hline Gryllus texensis & Sayre & Beckham & Oklahoma & 35.291 & 99.640 & $\mathrm{rt}-2-1$ \\
\hline Gryllus texensis & Sayre & Beckham & Oklahoma & 35.291 & 99.640 & $t-42-6$ \\
\hline Gryllus texensis & Sayre & Beckham & Oklahoma & 35.291 & 99.640 & $\mathrm{t}-42-7$ \\
\hline Gryllus texensis & Sayre & Beckham & Oklahoma & 35.291 & 99.640 & $\mathrm{t}-42-8$ \\
\hline Gryllus texensis & Sayre & Beckham & Oklahoma & 35.291 & 99.640 & $t-42-9$ \\
\hline Gryllus texensis & Sayre & Beckham & Oklahoma & 35.291 & 99.640 & $\mathrm{t}-42-10$ \\
\hline Gryllus texensis & Sayre & Beckham & Oklahoma & 35.291 & 99.640 & $\mathrm{t}-42-11$ \\
\hline Gryllus texensis & Sayre & Beckham & Oklahoma & 35.291 & 99.640 & $\mathrm{t}-42-12$ \\
\hline Gryllus texensis & Starkville & Oktibbeha & Mississippi & 33.450 & 88.818 & $\mathrm{t}-20-1$ \\
\hline Gryllus texensis & Starkville & Oktibbeha & Mississippi & 33.450 & 88.818 & $t-20-2$ \\
\hline Gryllus texensis & Starkville & Oktibbeha & Mississippi & 33.450 & 88.818 & $t-20-3$ \\
\hline Gryllus texensis & Starkville & Oktibbeha & Mississippi & 33.450 & 88.818 & $\mathrm{t}-20-4$ \\
\hline Gryllus texensis & Starkville & Oktibbeha & Mississippi & 33.450 & 88.818 & $t-20-5$ \\
\hline Gryllus texensis & Starkville & Oktibbeha & Mississippi & 33.450 & 88.818 & $\mathrm{t}-20-4$ \\
\hline Gryllus texensis & Starkville & Oktibbeha & Mississippi & 33.450 & 88.818 & $t-20-6$ \\
\hline Gryllus texensis & Starkville & Oktibbeha & Mississippi & 33.450 & 88.818 & $t-20-7$ \\
\hline Gryllus texensis & Starkville & Oktibbeha & Mississippi & 33.450 & 88.818 & $\mathrm{t}-20-8$ \\
\hline Gryllus texensis & Starkville & Oktibbeha & Mississippi & 33.450 & 88.818 & $t-20-9$ \\
\hline Gryllus texensis & Starkville & Oktibbeha & Mississippi & 33.450 & 88.818 & $\mathrm{t}-20-10$ \\
\hline Gryllus texensis & Starkville & Oktibbeha & Mississippi & 33.450 & 88.818 & $\mathrm{t}-20-11$ \\
\hline Gryllus texensis & Starkville & Oktibbeha & Mississippi & 33.450 & 88.818 & $t-20-12$ \\
\hline Gryllus texensis & Sulphur & Calcasieu & Louisiana & 30.236 & 93.377 & $\mathrm{t}-31-1$ \\
\hline Gryllus texensis & Sulphur & Calcasieu & Louisiana & 30.236 & 93.377 & $t-31-2$ \\
\hline Gryllus texensis & Sulphur & Calcasieu & Louisiana & 30.236 & 93.377 & rt-4-1 \\
\hline Gryllus texensis & Tallulah & Madison & Louisiana & 32.408 & 91.187 & $\mathrm{t}-24-1$ \\
\hline Gryllus texensis & Tallulah & Madison & Louisiana & 32.408 & 91.187 & $t-24-2$ \\
\hline Gryllus texensis & Tallulah & Madison & Louisiana & 32.408 & 91.187 & $t-24-3$ \\
\hline Gryllus texensis & Tallulah & Madison & Louisiana & 32.408 & 91.187 & rt-4-1 \\
\hline Gryllus texensis & Tallulah & Madison & Louisiana & 32.408 & 91.187 & $\mathrm{t}-24-4$ \\
\hline Gryllus texensis & Tallulah & Madison & Louisiana & 32.408 & 91.187 & $t-24-5$ \\
\hline Gryllus texensis & Tallulah & Madison & Louisiana & 32.408 & 91.187 & $t-24-6$ \\
\hline Gryllus texensis & Tallulah & Madison & Louisiana & 32.408 & 91.187 & $\mathrm{t}-24-7$ \\
\hline Gryllus texensis & Tallulah & Madison & Louisiana & 32.408 & 91.187 & $t-24-8$ \\
\hline Gryllus texensis & Tallulah & Madison & Louisiana & 32.408 & 91.187 & rt-4-1 \\
\hline Gryllus texensis & Tallulah & Madison & Louisiana & 32.408 & 91.187 & rt-4-1 \\
\hline
\end{tabular}


A PERIPATRIC ORIGIN FOR TWO SPECIES OF FIELD CRICKETS 3855

Appendix Continued

\begin{tabular}{|c|c|c|c|c|c|c|}
\hline Species & Population & County & State & $\begin{array}{l}\text { Latitude } \\
\text { (degrees North) }\end{array}$ & $\begin{array}{l}\text { Longitude } \\
\text { (degrees West) }\end{array}$ & Haplotype \\
\hline Gryllus texensis & Tallulah & Madison & Louisiana & 32.408 & 91.187 & $t-24-9$ \\
\hline Gryllus texensis & Tallulah & Madison & Louisiana & 32.408 & 91.187 & $\mathrm{t}-24-10$ \\
\hline Gryllus texensis & Tallulah & Madison & Louisiana & 32.408 & 91.187 & rt-1-1 \\
\hline Gryllus texensis & Tallulah & Madison & Louisiana & 32.408 & 91.187 & $t-24-11$ \\
\hline Gryllus texensis & Tallulah & Madison & Louisiana & 32.408 & 91.187 & $t-24-12$ \\
\hline Gryllus texensis & Tallulah & Madison & Louisiana & 32.408 & 91.187 & $t-24-13$ \\
\hline Gryllus texensis & Tuscaloosa & Tuscaloosa & Alabama & 33.210 & 87.569 & $\mathrm{t}-18-1$ \\
\hline Gryllus texensis & Tuscaloosa & Tuscaloosa & Alabama & 33.210 & 87.569 & $t-18-2$ \\
\hline Gryllus texensis & Tuscaloosa & Tuscaloosa & Alabama & 33.210 & 87.569 & rt-2-1 \\
\hline Gryllus texensis & Uvalde & Uvalde & Texas & 29.209 & 99.786 & $t-43-1$ \\
\hline Gryllus texensis & Uvalde & Uvalde & Texas & 29.209 & 99.786 & $t-43-2$ \\
\hline Gryllus texensis & Uvalde & Uvalde & Texas & 29.209 & 99.786 & $t-43-3$ \\
\hline Gryllus texensis & Uvalde & Uvalde & Texas & 29.209 & 99.786 & rt- $4-1$ \\
\hline Gryllus texensis & Uvalde & Uvalde & Texas & 29.209 & 99.786 & $t-43-4$ \\
\hline Gryllus texensis & Uvalde & Uvalde & Texas & 29.209 & 99.786 & $t-43-5$ \\
\hline Gryllus texensis & Uvalde & Uvalde & Texas & 29.209 & 99.786 & $t-43-6$ \\
\hline Gryllus texensis & Uvalde & Uvalde & Texas & 29.209 & 99.786 & $t-43-7$ \\
\hline Gryllus texensis & Uvalde & Uvalde & Texas & 29.209 & 99.786 & $\mathrm{t}-43-8$ \\
\hline Gryllus texensis & Uvalde & Uvalde & Texas & 29.209 & 99.786 & rt-1-1 \\
\hline Gryllus texensis & Uvalde & Uvalde & Texas & 29.209 & 99.786 & $t-43-9$ \\
\hline Gryllus texensis & Uvalde & Uvalde & Texas & 29.209 & 99.786 & rt-2-1 \\
\hline Gryllus texensis & Van Buren & Crawford & Arkansas & 35.437 & 94.348 & $\mathrm{t}-32-1$ \\
\hline Gryllus texensis & Van Buren & Crawford & Arkansas & 35.437 & 94.348 & $t-32-36-1$ \\
\hline Gryllus texensis & Van Buren & Crawford & Arkansas & 35.437 & 94.348 & rt-4-1 \\
\hline
\end{tabular}

*haplotypes marked with asterisk occurred in numerous populations; specifically, rt-1-1: 1, 2, 3, 4, 5, 6, 7, 8, 9, 10, 11, 12, 13, 15, 17, 18, 21, 24, $26,28,30,33,36,37,38,39,40,43 ;$ rt-2-1: 2, 3, 4, 6, 8, 11, 12, 13, 15, 16, 17, 18, 21, 22, 25, 26, 27, 28, 30, 32, 33, 34, 39, 40, 41, 42, 43; rt-4-1: 4, 6, $24,26,30,31,32,33,34,35,37,38,40,43$.

(C) 2008 The Authors

Journal compilation @ 2008 Blackwell Publishing Ltd 